\title{
Dördüncü sanayi devriminde kamu destekli gelişmeler: Seçilmiş ülkeler ve Türkiye karşılaştırması*
}

\section{Publicly supported developments in the fourth industrual revolution: Comparison of selected countries and Turkey}

\section{Gülsema Çetinkaya ${ }^{1}$ (iD Nazan Susam ${ }^{2}$ \\ 1 Araş. Gör., Bandırma Onyedi Eylül Üniversitesi, İktisadi ve İdari Bilimler Fakültesi, Maliye Bölümü, Türkiye, e-mail: gcetinkaya@bandirma.edu.tr 2 Prof. Dr., İstanbul Üniversitesi, İktisat Fakültesi, Maliye Bölümü, Türkiye, e-mail: nsusam@istanbul.edu.tr}

Öz

Dördüncü sanayi devrimi, pek çok ülkede kamu yatırım ve transfer harcamalarını, AR-GE çalışmalarını, kamu destek ve teşviklerini belli ölçülerde artırmıştır. Elde edilen veriler ile yapılan kamusal harcamaların ve desteklerin ülke ekonomisinin büyümesi ve kalkınması için önemli bir yere sahip olduğunu söylemek mümkündür. Bu çalışmanın amacı, dördüncü sanayi devriminin kamu harcamaları üzerindeki etkisini incelemektir. Her bir sanayi devriminde ortaya çıkan yeni teknolojiler dünyanın biraz daha küçülmesine neden olarak küreselleşmeyi hızlandırmıştır. Dahası bu gelişmeleri başarıyla takip edebilen ülkeler de küresel rekabette üstünlük elde etmeye başlamıştır. Bu durum hükümetlerin dördüncü sanayi devrimi ile yaşanan dijital dönüşümü kamu harcamaları ve altyapı çalışmaları ile desteklemesinde etkili olmuştur.

Anahtar kelimeler: Endüstri 4.0, Dördüncü sanayi devrimi, dijital dönüşüm, kamu harcamaları

JEL kodları: E61, E62, H50, O14

\begin{abstract}
The fourth industrial revolution has increased public investment and transfer expenditures, R\&D studies, public support and incentives to a certain extent in many countries. With the obtained data, it is possible to say that public expenditures and supports have an important place fort he growth and development of the country's economy. The aim of the study is to examine the impact of the fourth industrial revolution on public expenditures. The new technologies that emerged in each industrial revolution has accelerated globalization by making the world a little smaller. Moreover, countries that have successfully followed these developments have begun to gain an advantage in global competition. This situation has been effective in the governments supporting the digital transformation experienced with the fourth industrial revolution with public expenditures and infrastructure works.
\end{abstract}

Keywords: Industry 4.0, Fourth industrial revolution, digital transformation, public expenditures

JEL codes: E61, E62, H50, O14

*Bu makale İstanbul Üniversitesi Sosyal Bilimler Enstitüsü Maliye Yüksek Lisans Programında hazırlanmış olan “Dördüncü Sanayi Devriminin Kamu Harcamaları Üzerine Etkisi” başlıklı Yüksek Lisans tezinden üretilmiştir.

Citation/Atıf: ÇETINKAYA, G. \& SUSAM, N., (2021). Dördüncü sanayi devriminde kamu destekli gelişmeler: Seçilmiş ülkeler ve Türkiye karşılaştırması. Journal of Life Economics. 8(4): 413-429, DOI: 10.15637/jlecon.8.4.02

Corresponding Author/ Sorumlu Yazar: Gülsema Çetinkaya

E-mail: gcetinkaya@bandirma.edu.tr
Bu derginin içerĭ̌̆ Creative Commons Attribution-NonCommercial 4.0 Uluslararası Lisansı altında lisanslanmıı̧tır.

Content of this journal is licensed under a Creative Commons Attribution-NonCommercial 4.0 International License. 


\section{GIIRIŞ}

Günümüz dijital dönüşüm çağının temelleri yüzyıllar öncesinde yaşanan devrim niteliğindeki gelişmelere dayanmaktadır. Bu devrimlerin başında 18. yüzyıl sonlarında buhar makinesinin üretim sistemlerinde kullanılmasıyla başlayan birinci sanayi devrimi yer almaktadır. Daha sonra 19. yüzyılın son çeyreğinde elektik gücünün de üretim süreçlerinde kullanılmaya başlanması ile ikinci sanayi devrimi, 20. yüzyılın ikinci yarısından itibaren elektronik, bilgisayar ve bilgi iletişim teknolojilerinin gelişmesi ve üretim süreçlerine entegre edilmesiyle de üçüncü sanayi devrimi ortaya çıkmıştır.

Bilişim teknolojilerinin hızla gelişmeye başlaması ve bu teknolojileri uygulamayı başaran ülkelerin küresel rekabette büyük avantaj elde etmeleri başta Almanya olmak üzere ülkeleri yeni sanayileşme stratejileri oluşturmaya yönlendirmiştir. Bu kapsamda 2011 yılında Almanya'nın kamu politikası olarak geliştirdiği Endüstri 4.0 stratejisi ile dördüncü sanayi devrimi başlamıştır. Endüstri 4.0 kavramı daha sonra pek çok çalışmada dördüncü sanayi devrimini tanımlamak için de kullanılmıştır.

Günümüzde ülkelerin dijital dönüşümü tamamlanması, ülke ekonomilerinin küresel pazarda önemli bir yer alması ve rekabet güçlerini artırmaları açısından son derece önemlidir. Bu kapsamda devletin ekonomiye müdahalesi de dijital dönüşümü destekleyici alanlara kaymıştır. Devlet ve bu alanda görev alan kamu birimleri altyapı çalışmalarını, fonlar, sübvansiyonlar ve teşvikler yoluyla desteklemeye başlamıştır.

Bu çalışmada dördüncü sanayi devriminin gelişiminde kamu kesimi tarafından gerçekleştirilen harcamalar ve destekler incelenecek ve dördüncü sanayi devriminin kamu harcamaları üzerindeki etkisi ele alınacaktır. Çalışma kapsamında ilk olarak Endüstri 4.0 öncesi sanayi devrimleri ve devrimler çerçevesinde kamu harcamalarının gelişimi daha sonra dördüncü sanayi devrimi ve bileşenleri ele alınmaktadır.
Ardından dördüncü sanayi devriminin gelişiminde önemli bir yere sahip olan Almanya, Çin ve ABD'de yürütülen Endüstri 4.0 girişimleri, bu ülkelerde dördüncü sanayi devrimine yönelik kamu harcamaları ve destekleri ele alınmıştır. Bu girişimlerin ülkelerin yüksek teknoloji ihracatı ve bilgi iletişim teknolojileri mal ithalatı üzerindeki etkileri incelenmiştir. Son olarak da Türkiye'nin sanayileşme süreci ile dördüncü sanayi devrimine yönelik çalışmaları ele alınarak yaşanan dijital dönüşüm sürecinde Türkiye'nin geliştirdiği stratejiler ve bu stratejiler kapsaminda kamu tarafından gerçekleştirilen harcamalar ve destekler incelenmiştir.

\section{ENDÜSTRİ 4.0 ÖNCESİ SANAYİ DEVRIMLERİ VE KAMU HARCAMALARI}

Sanayi devrimi 18. yüzyılın başlarında ortaya çıkan teknolojik gelişmelerin ekonomideki hemen her sektörü geliştirmesi ile ortaya çıkan iktisadi büyüme olarak tanımlanabilir. Ancak sanayi devrimleri incelenirken yalnızca sanayi ve teknoloji alanlarında yaşanan gelişmeleri ele almak doğru değildir. Tarımsal gelişmeler, nüfus artışı, ulaşım ve ticaret alanlarındaki gelişmeler, sermaye birikiminin sağlanması ve teknolojik gelişmelerin aynı dönemlerde eş zamanlı olarak yaşanması sanayi devriminin ortaya çıkmasında etkili olmuştur. Bu kapsamda sanayi devrimini hazırlayan faktörler Şekil 1'de gösterilmektedir.

Şekil 1'e göre sanayi devriminin oluşum süreci incelendiğinde, geçmişte yaşanan tüm sosyal, siyasal, demografik, ekonomik ve teknolojik gelişmeler birikerek ve dönemin tüm dinamiklerini yanına alarak devrimin baş mimarları olarak yerlerini almışlardır (Küçükkalay, 1997: 58).

Bu faktörler 1760'lı yıllarda başlayarak 1840'lı yıllara kadar süren ilk sanayi devriminin gelişiminde etkili olmuştur. Devrim, buhar makinesinin icat edilmesi ve demiryollarının inşa edilmeye başlanması ile birlikte mekanik üretime öncülük etmiştir (Schwab, 2017: 16).

Şekil 1. Sanayi Devriminin Oluşum Nedenleri

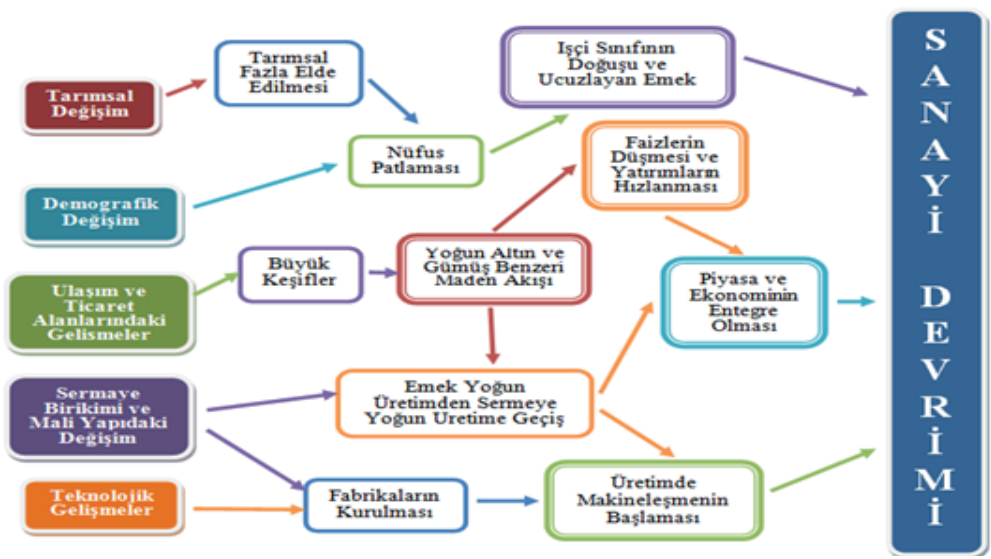

Kaynak: Tarafımızca hazırlanmıştır. 
Dolayısıyla birinci sanayi devrimi, el ve beden emeğine dayalı üretimden makine gücüne dayalı üretim sistemine geçildiği, buhar makinesinin ve pamuğun dokuma sanayiinde kullanılmaya başlandığı, fabrikaların kurulduğu ve yakıt olarak kömürün kullanılmaya başlandığı bir süreçtir (EBSO, 2015: 4).

İlk sanayi devrimi, 19. ve 20. yüzyıllarda gerçekleşen diğer devrimlerden farklı olarak, özel sermaye ve bireysel girişimciler tarafından finanse edilen bir devrim konumundadır. Bu süreçte herhangi bir sanayileşme politikası olmayan hükümet, devrimin gerçekleşmesinde önemli bir rol oynamamış, aksine "laissez-faire" politikasını benimsemiştir. Vergilendirme oranlarının çok düşük olduğu bu dönemde kamu harcamaları esas olarak askeri harcamalar ve kraliyet masrafları şeklinde yapılmış bununla birlikte yalnızca demiryollarının inşası, lokomotif ile yolcu ve yük taşıma hizmetleri ve bankacılık faaliyetlerinin gelişimi için kamusal destekler sağlanmıştır (Harris, 2004: 204; Görçün, 2017: 18, 28).

Birinci sanayi devriminin ardından 1870-1914 yılları arasında ikinci sanayi devrimi gerçekleşmiştir. İlk sanayi devriminde yaşanan gelişmelerin artarak devam ettiği bu dönemde özellikle çelik üretim tekniklerinin geliştirilmiş, içten yanmalı motorlar, okyanus ötesi telgraf ve radyo gibi teknolojik buluşlar ortaya çıkmış, buhar enerjisi yerine elektrik enerjisi, kömür yerine de petrol kullanılmaya başlanmış ve seri üretime geçilerek üretim devasa boyutlarda artırılmıştır. Ortaya çıkan bu buluşlar ve yenilikler aracılığıyla iletişim ve ulaşım kolaylaşmış, üretim çeşitlenmiş ve verimlilik hızla artmıştır.

İkinci sanayi devriminin başlarında, birinci sanayi devriminde olduğu gibi laissez-faire ilkesi benimsenmiş olsa da kamu harcamaları ulusal gelirin önemli bir oranına ulaşmıştır. Bu harcamalar başlangıçta yollar, su temini ve kanalizasyon hizmetleri, halk sağlığ ve gaz çalışmaları alanlarında yapılmıştır. 1900'lü yılların başlarına doğru ise elektrik arzı, tramvaylar ve eğitim harcamaları şeklinde hem endüstriyel hem de kişisel talepleri karşılamak üzere genişletilmiştir. Bu süreçte Avrupa'da da kişi başına yıllık kamu harcamaları üç katına çıkmış ve kamu müdahaleleri de daha çok düzenleme amacıyla yapılmıştır (Hobsbawm, 1998: 208-214; Milward ve Sheard, 1995: 503). Birinci Dünya Savaşı'nın ardından birçok ülke bilimsel araştırma geliştirme (Ar-Ge) faaliyetlerine destek vermeye başlamış ancak genel olarak askeri sanayiin geliştirilmesine yoğunlaşılmıştır (Freeman ve Soete, 2003: 426).

1960 ve 1970'li yıllarda başlayan üçüncü sanayi devrimi ise elektronik, bilgi ve iletişim teknolojilerinin gelişmesi sonucu üretimde otomasyonun sağlandığ dönemdir. Üçüncü sanayi devrimi, 1960'l1 yıllarda ana bilgisayarların, 1970 ve 1980'lerde kişisel bilgisayarların ve 1990'lı yıllarda internetin yaygınlaşması ile ge- lişmesi nedeniyle bilgisayar devrimi ya da dijital devrim olarak da adlandırılmaktadır (Schwab, 2017: 16). Bu devrimde, iş bölümüne dayalı mekanik ve elektronik teknolojiyle çalışan makinelerin yerini elektronik ve bilgi teknolojisine dayalı dijital teknolojiyle çalışan makineler almaya başlamıştır (Kagermann vd., 2013: 14). Ayrıca önceki devrimlerde kullanılan fosil yakıtların yerine üçüncü sanayi devriminde nükleer ve yenilenebilir enerji kaynakları önem kazanmaya başlamıştır (Rifkin, 2014: 57).

Üçüncü sanayi devriminin başlarında (1950 ve 1960'lı yıllar), İkinci Dünya Savaşı'nın da etkisiyle kamu harcamaları büyük oranda nükleer, askeri ve uzay programlarının gelişimini desteklemek amacıyla yapilmıştır (Freeman ve Soete, 2003: 437). Daha sonra inovasyon faaliyetlerinin ortaya çıkmasıyla birçok ülkede hükümetler, yeni teknolojileri geliştirmek ve yaygınlaştırılmasını sağlamak ve böylece ekonomik büyümeyi desteklemek amacıyla Ar-Ge faaliyetlerine önem vermeye başlamıştır. Bu kapsamda birçok ülkede de ulusal inovasyon stratejileri ve teknoloji politikaları tasarlanmaya ve uygulanmaya başlamıştır (UNIDO, 2015: 151). Zira önceki devrimlerde devrimin teknolojilerine uyum sağlayabilen ülkeler küresel rekabette büyük bir güç elde etmişlerdir.

Üçüncü sanayi devriminin başında 1973 yılında 100 milyar \$ olan Ar-Ge harcamalarının küresel toplamı, yıllar boyunca sürekli artarak on kattan fazla bir artışla 2007'de yaklaşık 1,138 milyar \$'a yükselmiştir. Ancak bu miktar GSYH'ya oranla ölçüldüğünde dünya ekonomisinin genel büyümesini pek sürdürememiştir. Zira 1973'te \%2,1 olan Ar-Ge harcamalarının GSYH'ya oranı, 1990 ve 2007 yılları arasında yaklaşık \%1,7 oranında gerçekleşmiştir (Arond ve Bell, 2009: 16).

\section{DÖRDÜNCÜ SANAYİ DEVRIMİ VE BILLEŞENLERI}

Üçüncü sanayi devriminde ortaya çıkan bilgisayar donanımları, yazılımlar ve dijital teknolojilerin hızla gelişerek bütünleşmeye başlaması günümüzde $\mathrm{Al}$ manya'nın sanayi politikası olarak geliştirdiği "Endüstri $4.0^{\prime \prime}$ stratejisini ortaya çıkarmasını sağlamış ve dördüncü sanayi devrimi sürecini başlatarak toplumları ve ekonomiyi derin bir dönüşüme uğratmıştır. Bu nedenle devrim, Endüstri 4.0 olarak da adlandırılmaktadır.

Endüstri $4.0^{\prime}$ ın temelinde bilişim ve iletişim alanında yaşanan gelişmeler ile insana ihtiyaç duymadan otonom bir şekilde faaliyette bulunabilen makinelerin üretim sistemlerine uyumlaştırılması bulunmaktadır. Bu kapsamda dördüncü sanayi devrimi, üretim ve tüketim süreçlerinin birbirleri ile tamamen entegre hale geldiği, üretim süreçlerinde otomasyonun en üst düzeylerde uygulandığı ve insan faktöründen arınd1rılmış bir üretim sisteminin yaratıldığı bir devrimdir. 
Schwab (2017: 9)'a göre bu yeni devrim yaşama, çalışma ve insanların birbirleri ile iletişim kurma tarzını kökten değiştirmekte ve fiziksel, dijital ve biyolojik teknolojileri iç içe geçirmektedir. Günümüzde yaşanan teknolojik ilerlemelerin tamamı dördüncü sanayi devriminin gelişimine katkı sağlamakla birlikte büyük veri, bulut bilişim, üç boyutlu yazıcılar, nesnelerin interneti, yapay zekâ ve otonom robotlar, siber fiziksel sistemler ve simülasyon, akıllı fabrikalar, sistem entegrasyonu, artırılmış gerçeklik ve siber güvenlik bileşenleri devrimin gelişimine katkı sağlayan temel faktörlerdir. Bu bileşenlerin etkinlik düzeyleri ve birbirleri ile uyumu endüstrileşme sürecinin başarı ile tamamlanması açısından son derece önemlidir. Bu bileşenler kısaca aşağıdaki gibidir:

- Siber fiziksel sistemler, tüm üretim, depolama, lojistik gibi süreçlerin birbiriyle bağlantılı olmasını sağlayan, bu üretim süreçleri içerisinde gerçekleştirilen operasyonları en yüksek performans düzeyinde yöneten ve üretim süreçleri arasındaki entegrasyonu en üst düzeyde sağlayarak yürüten otonom sistemlerdir.

- Simülasyon, makine, ürün ve insan içeren, gerçek zamanlı verilerden faydalanarak fiziksel dünyayı dijital dünyaya taşıyan ve böylece makine kurulum sürelerini azaltarak zaman, maliyet ve risk yönetimini kolaylaştıran bir modelleme teknolojisidir.

- Nesnelerin interneti makinelerin, sensörlerin ya da günlük hayatta kullanılan cihazların kendi bünyelerinde mevcut olan internet ve bilişim teknolojileri sayesinde insan müdahalesine gerek kalmadan kendi aralarında iletişim kurmalarına ve bu iletişim sonucunda toplanan bilgiler ile kendi kendilerine karar vererek faaliyete geçebilmelerine olanak tanıyan bir teknolojidir.

- Büyük veri, internetin hızlı gelişimi ile birlikte üretilen büyük miktarlardaki verinin toplanması, işlenmesi ve analiz edilmesini sağlayan teknolojidir. Bu teknoloji, sürekli büyüyen veri tabanının hızlı ve verimli bir şekilde yönetilmesi ve kullanılmasına olanak tanımaktadır.

- Bulut bilişim, mevcut tüm veri, program ve uygulamanın sanal bir sunucuda depolanması ve internete bağli olunan herhangi bir ortamda cihazlar aracılığıyla bu programlara, verilere ve bilgilere kolayca ulaşımın sağlandığı ve böylece altyapı karmaşasının ortadan kaldırıldığ 1 bir "online" hizmetler bütünüdür.

- Katmanlı üretim ve üç boyutlu yazıcılar, dijital ortamda tasarlanmış herhangi bir üç boyutlu nesnenin sanal olarak katmanlara bölünmesi ve her bir katmanın eritilen malzeme ile üst üste gelecek şekilde basılması yoluyla çalışmaktadır.
- Yapay zekâ, makinelere, robotlara ve uygulamalara insanların sahip olduğu zekânın aktarılması ile insanların yapabildiği işlerin bu makineler, robotlar ve uygulamalar aracılığıly da yapılabilmesini sağlayan bir teknolojidir.

- Otonom robotlar, içerdikleri gömülü bilişim donanımları ile yapay zekâ uygulamalarını gerçekleştirerek eyleme dönüştürebilen, insan müdahalesi olmadan el, kol vb. uzuvlarını kullanabilen, hareket edebilen ve uzun süre kendi başına çalışabilen, çevresi hakkında veri toplayarak bilgi edinebilen, diğer akıllı ve bağlantılı nesneler ile iletişim kurabilen ve insanlara, çevresine veya kendisine zararlı durumlardan kaçınabilen makinelerdir.

- Akıllı fabrikalar, geniş bir ağ üzerinde performanslarını kendi kendine optimize edebilen, neredeyse gerçek zamanlı olarak yeni koşullara uyum sağlayabilen ve bunları öğrenerek tüm üretim süreçlerini bağımsız olarak çalıştırabilen esnek üretim sistemleridir.

- Sistem entegrasyonu, üretim süreçlerinin bütün bileşenlerinin birbirleriyle gerçek zamanlı ve sürekli olarak iletişim içerisinde olmasını sağlamasına, böylece akıllı ve kendini yönetebilen makine-makine etkileşimlerinin daha hızlı, verimli ve yüksek kalitede bir dijital dönüşümün yaşanmasina olanak tanımaktadır.

- Artırılmış gerçeklik, gerçek dünyadaki ortamların bilgisayar aracılığıyla üretilen görüntü, ses, grafik ve GPS verilerinin zenginleştirilmesiyle oluşturulan canlı, doğrudan veya dolaylı fiziksel görüntülerden oluşan bir teknolojidir.

- Siber güvenlik, sanal ortamda bireysel kullanıcıların ve kuruluşların varlıklarını korumak amacıyla kullanabilecekleri araçlar, politikalar, yönergeler, eylemler, güvenlik önlemleri, güvenlik kavramları, risk yönetim yaklaşımları, eğitim başta olmak üzere en iyi uygulama ve teknoloji-


sanal ortamlardaki ilgili siber riskler ve tehditlere karşı kullanıcıların ve kuruluşların varlıklarının güvenlik özelliklerine ulaşmasını ve korunmasını sağlanmasıdır.

Dördüncü sanayi devrimi ile birlikte hiz kazanan bu teknolojik gelişmeler, tüm dünyada dijital bir dönüşümün yaşanmasında etkili olmuştur. Bu süreçte geliştirilen teknolojiler, insan emeğini en aza indirerek hata oranlarının azalmasına, kaynak israfının önüne geçilmesine ve dolayısıyla üretkenlik, verimlilik ve kârlılığın artırılmasına, maliyetlerin düşürülmesine, yeni iş olanaklarının yaratılmasına ve daha pek çok avantajın ortaya çıkmasına zemin hazırlamıştır. Ancak bu avantajların yanı sıra birtakım dezavantajları da bulunmaktadır. Bu dezavantajların başında En- 
düstri 4.0 teknolojilerinin vasıfsız insan emeğine olan ihtiyacı azaltması bulunmaktadır. Bu durum işsizlik sorunlarının ortaya çıkmasına ve gelir eşitsizliklerinin yaşanmasına neden olabilecektir. Dolayısıyla istihdam üzerinde olumsuz bir etki yaratarak önemli vergi ve sosyal güvenlik kayıplarının da yaşanmasına ortam hazırlayacaktır. İlgün (2020)'e göre, ortaya çıkacak istihdam sorunları ve gelir eşitsizlikleri sosyal transfer harcamaları üzerinde dramatik bir dönüşüme neden olarak bu harcamaların önemli oranlarda artmasına neden olacaktır.

\section{SEÇİLMISŞ ÜLKELERDE ENDÜSTRİ 4.0 UYGULAMALARI VE KAMU HARCAMALARI}

Endüstri 4.0'ın temelinde fabrikaların, şirketlerin ve imalat endüstrilerinin dijital teknolojiler ile donatılması yer almaktadır. Dijital dönüşüm sürecinin başlamasının ardından birçok ülkede araştırma ve geliştirme faaliyetleri ve dolayısıyla AR-GE harcamaları önemli ölçüde artmıştır.

Huawei ve Oxford Economics (2017: 24)'in hazırlamış olduğu rapora göre, son otuz yılda teknoloji dışında yapılan her $1 \$$ tutarındaki yatırım GSYH'da $3 \$$ getiri sağlarken, dijital teknolojilere yapılan her $1 \$$ tutarındaki yatırım ortalama $20 \$$ getiri sağlamaktadır. Dolayısıyla dijital teknolojilere yapılan her $1 \$$ tutarındaki yatırımın GSYH'ya katkısının, dijital olmayan teknolojilere göre 6.7 kat daha yüksek olduğu görülmektedir. Dahası, küresel çapta yüksek bir dijitalleşme senaryosu başarısının 2025 yılında küresel GSYH'yı 1,7 trilyon \$ artıracağı tahmin edilmektedir. Bu kapsamda 2025 yılına kadar dijital teknolojilerin, küresel GSYH'nın \%24,3'ü oranında katkı yapacağı düşünülmektedir.

Bu süreçte bir ülkenin dijital dönüşümünü tamamlayabilmesi için o ülkedeki özel sektörün girişimleri yeterli değildir. Devlet tarafından da desteklenmesi gerekmektedir. Nitekim pek çok ülkede kamu çalışmaları ile planlar, projeler, stratejiler veya yol haritaları belirlenerek özel sektörün dijital dönüşümünü gerçekleştirmesine yönelik çalışmalar yapılmakta ve bu alandaki yatırım harcamaları artırılmaktadır. Hükümetler dijital dönüşümün tamamlanması için Endüstri 4.0'a yönelik girişimler hazırlamak ve yürütmekle birlikte ayrıca özel sektörün kendi dönüşümünü sağlayabilmesi için destekler, teşvikler veya sübvansiyonlar da sağlamaktadır. Bu durum yatırım harcamalarının yanında transfer harcamalarının da artmasına neden olmaktadir.

Söz konusu dijital dönüşüm süreci ve kullanımı yalnızca özel sektör ile sınırlı değildir. Bu teknolojiler aynı zamanda kamu sektöründe de artan şekilde kullanılmaya başlamıştır. Özellikle büyük veri, nesnelerin interneti, yapay zekâ, bulut bilişim ve siber güvenlik teknolojilerinin kamu kurum ve kuruluşla- rında, kamu hizmetlerinin sunumunda kullanılması, iş yükünün, israfın ve hata oranlarının azaltılmasını sağlayarak kamu hizmetlerinde etkinlik, verimlilik ve şeffaflığın artırılmasını ve kamu hizmetlerinin kalitesinin iyileştirilmesini mümkün kılmaktadır (Çetinkaya ve Akar, 2020: 214). Bu çerçevede kamu sektöründe dijital teknoloji altyapısının oluşturulmasının ardından cari harcamaların zamanla azalacağı yargısına ulaşılmaktadır.

Bir ülkenin hazırlamış olduğu girişimler, planlar, politikalar, stratejiler vs. çerçevesinde dijital dönüşümdeki başarısı, söz konusu ülkenin yüksek teknoloji girişimleri ile gelişim göstermektedir. Zira bu ülkelerde yapılan yüksek teknoloji ihracatı oranları, o ülkelerin dijital ekonomide ne kadar söz sahibi olduğunu ifade etmektedir. Bu nedenle ülkeler, dijital ekonomide hızla ilerleyebilmek için teknoloji üretimini destekleyen yatırımlar yapmaktadır. Dijital ekonomide yüksek teknoloji ihracatının artması, o ülkenin dijitalleşme başarısını da artırmaktadır.

Ülkelerin dijital dönüşümünü tamamlaması aynı zamanda yeterli bilgi iletişim teknolojisi altyapısına sahip olmasına bağlıdır. Bu nedenle hazırlanan plan, politika ve stratejilerde genellikle bu teknolojilerin ülke içinde üretilmesi hedeflenmiştir. Ancak dijital dönüşümün tamamlanmasına yönelik hazırlanan girişimlerin uzun dönemli olarak planlanması nedeniyle kısa dönemde bu teknolojiler bilgi iletişim teknolojisi mal ithalatı ile sağlanmaktadır. Bu çerçevede dijital dönüşüm sürecini daha iyi açıklayabilmek ve anlayabilmek amacıyla Ar-Ge harcamaları oranı, yüksek teknoloji ihracatı ve bilgi iletişim mal ithalatı göstergelerinin ele alınması gerekmektedir.

Çalışma kapsamında Avrupa, Asya ve Amerika kıtalarından en önemli girişimlere imza atan Almanya, Çin ve Amerika Birleşik Devletleri ele alınmıştır. Bu ülkeler Endüstri 4.0 uygulamaları ve mevcut teknolojik atılımları ile genel ekonomik durumlarını iyileştiren öncü ülkeler olarak dördüncü sanayi devriminin gelişiminde önemli bir yere sahiptir (Kagermann vd., 2016: 37). Nitekim World Economik Forum ve A.T. Kearney (2018) firması tarafından hazırlanan "Üretimin Geleceğine Hazırlık Raporu 2018"'de de bu ülkeler dördüncü sanayi devriminde lider ülkeler arasında yer almaktadır. Dolayısıyla bu bölümde bu ülkelerin dördüncü sanayi devrimine uyum sağlamak amacıyla yapmış oldukları yatırım ve transfer harcamaları ele alınacaktır. Bu ülkelerin Endüstri 4.0 sürecinde dijital dönüşüm seviyelerinin değerlendirilmesi için GSYH içerisindeki AR-GE harcamaları oranı ve son yıllarda uluslararası ticaretin en dinamik bileşenlerinden olan yüksek teknoloji ihracatı ve bilgi iletişim teknolojileri mal ithalatı göstergelerine de değinilecektir. Bu göstergeler değerlendirilen ülkelerde dördüncü sanayi devrimine yönelik yapılan çalışmaların ne kadar etkili olduğunun ele alınması ve bu ülkelerin karşılaştırıl- 
ması açısından önem arz etmektedir.

\subsection{Almanya Örneği}

Sanayileşme sürecinde dünyanın öncü ülkelerinden birisi olan Almanya, dördüncü sanayi devrimine "Endüstri 4.0" girişimi ile 2011 yılında başlamıştır. Bu girişim 2012 yılında Alman hükümetinin Federal Eğitim ve Araştırma Bakanlığ 1 (BMBF) ve Federal Ekonomik İşler ve Enerji Bakanlığı (BMWI) aracılığıyla hükümet programına alınmış ulusal bir stratejik girişimdir ve geleceğe ilişkin güçlü, teknoloji tabanlı bir vizyonu tanımlamaktadır. Endüstri 4.0'ın odak noktası üretim süreçlerinin dijitalleşmesi ile kalite, fiyat ve esnekliği optimize etmek ve daha iyi finansal getiri sağlamaktır. Stratejik hedefi ise Almanya'nın dijital dönüşüm sürecinde imalat ve makine mühendisliğindeki güçlü konumunu korumaktır. Ayrıca bu girişim ile birlikte teknolojik araştırmaların, endüstri partnerlerine ortak bir ağ oluşturulmasının ve standardizasyonun desteklenmesi amaçlanmaktadır (Kagermann vd., 2016: 9; Klitou vd., 2017: 3).

Endüstri 4.0 girişiminin ardından 2013 yılında Federal Bilgi Teknolojisi, Telekomünikasyon ve Yeni Medya Birliği (BITKOM), Alman Mühendislik Federasyonu (VDMA) ve Elektrik ve Elektronik Üreticileri Birliği (ZVEI) öncülüğünde politika yapıcılar için merkezi bir iletişim noktası görevi gören Endüstri 4.0 Platformu (Platform Industrie 4.0) kurulmuştur. Bu platform ile şirketler, sendikalar, dernekler, bilim ve siyaset birimleri arasında iletişim sağlanarak dijital dönüşümün hızlandırılması hedeflenmiş ve Alman endüstrisinin dijital dönüşümünü koordine edilmesi amaçlanmıştır. Platform, 2015 yılında BMBF ve BMWI'nın desteği ile genişletilmiştir (Platform Industrie 4.0, 2019: 1-2).

Endüstri 4.0 öncesinde dahi araştırma, geliştirme ve inovasyon Almanya'nın refah ve rekabet gücünü oluşturan faktörlerdir. Bu nedenle Endüstri 4.0 ile birlikte Ar-Ge harcamalarını büyük miktarlarda artıran Alman hükümeti, Endüstri 4.0 girişiminin desteklenmesine de son derece önem vermektedir. Bu kapsam- da 2011 yılında BMBF (120 milyon €) ve BMWI (80 milyon €) aracılığıyla Endüstri 4.0 girişimi için 200 milyon $€$ finansman sağlamıştır (Klitou vd., 2017: 4). Bununla birlikte özellikle Almanya'nın küreselleşmesi ve dijitalleşmesine yönelik çalışmalar yürüten BMWI bütçesinden Endüstri 4.0'a yönelik harcamalar için her geçen yıl daha büyük miktarlarda finansman tahsis edilmiştir.

2005-2017 yılları arasında federal hükümetin Ar-Ge harcamaları, 9,0 milyar $€$ artarak 2017'de 16,6 milyar $€^{\prime}$ ya ulaşmıştır. 2017 yılında hükümet ve sanayi birlikte 99,6 milyar $€$ ile \%3,04'e ulaşan Ar-Ge harcamalar1nın GSYH'ya oranı, 2018 yılında \%3,09'a, 2019 yılında ise yaklaşık \%3,2'ye yükselmiştir (Şekil 2). 2019 yılında gerçekleşen 109,5 milyar €'ya ulaşan toplam Ar-Ge harcamalarının \%14'ü kamu sektörü tarafından yapılmıştır. Eylül 2018'de kabul edilen Yüksek Teknoloji Stratejisi kapsamında AR-GE harcamaları GSYH'ya oranının 2025 yılında \%3,5'e ulaşması hedeflenmektedir. Bu oranlarla Almanya, Avrupa Birliği'ndeki tüm AR-GE harcamalarının \%30'unu oluşturmaktadir (BMBF, 2020; BMBF, 2019: 7: Destatis Statistisches Bundesamt, 2021).

Endüstri 4.0 girişimi ile Almanya'da büyük bir katma değer yaratılmış ve yazılım, donanım ve bilgi teknolojileri hizmetleri 2016 ve 2017 yıllarında \%20'den fazla büyüme kaydetmiştir. Bu büyümenin ilerleyen yıllarda katlanarak devam etmesi ve 2025 yılına kadar 425 milyar $€^{\prime}$ ya varan bir katma değer potansiyeli yaratması öngörülmektedir. Zira tüm endüstriyel üretim süreçlerinin yaklaşık $\% 90$ ' 1 bilgi iletişim teknolojileri (BİT) tarafından desteklenmektedir. Bu süreçte en çok gelişen sektörlerden biri Almanya'nın en büyük endüstri sektörü olan otomotiv endüstrisidir. 2016 yılında otomotiv sektörü için 21 milyar €'dan fazla inovasyon harcaması yapılmış ve toplam AR-GE harcamalarının yaklaşık \%35'i de otomotiv sektörü için ayrılmıştır. Böylece Almanya'nın en büyük ihracat endüstrisi olan otomotiv sektörü aynı zamanda Almanya'nın dünya ihracat lideri olmasını da sağlamıştır (MacDougall, 2018: 3-6).

Şekil 2. Almanya'nın AR-GE Harcamaları, BİT Mal İthalatı ve Yüksek Teknoloji İhracatı Göstergeleri (2006-2019)

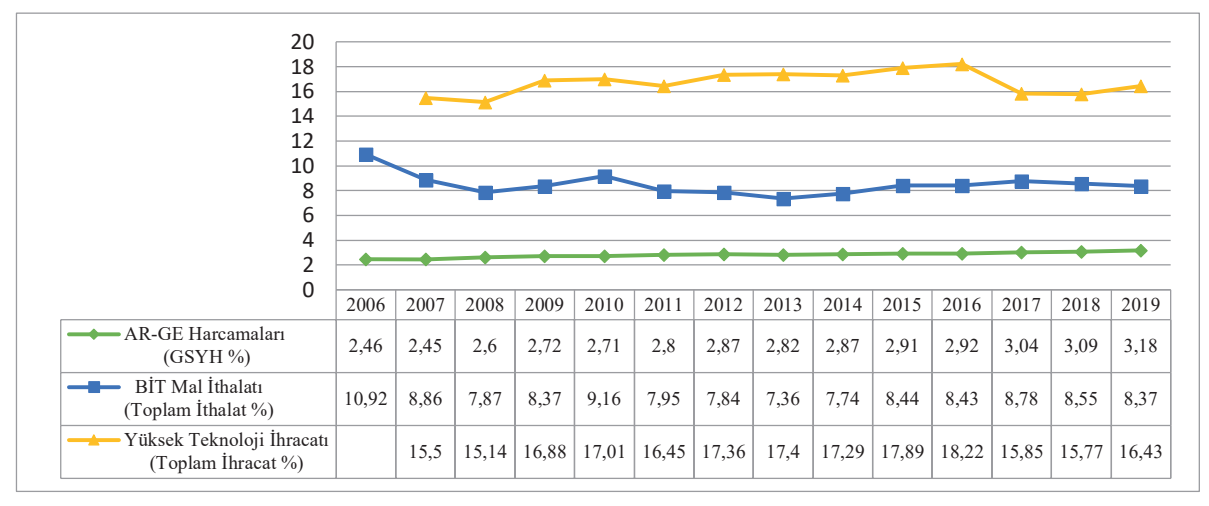

Kaynak: World Bank Data (2021), Destatis Statistisches Bundesamt (2021)'den yararlanılarak oluşturulmuştur. 
2007 yılında Avrupa'nın en büyük BİT ihracatçısı ve ithalatçısı konumunda yer alan Almanya'da (OECD, 2009: 90), toplam ithalat içindeki BİT mal ithalatı oranı yıllar içerisinde sürekli dalgalanmalar göstermiş ve 2019 yılında \%8,37 oranında gerçekleşmiştir. Endüstri 4.0 girişiminin başladığı 2011 yılından itibaren genel olarak artış eğilimi gösteren yüksek teknoloji ihracatı oranı ise 2017 yılında büyük bir düşüş yaşamış ancak daha sonra yeniden artarak 2019 yılında \%16,43 oranında gerçekleşmiştir. 2017 yılında yaşanan düşüşün temelinde, Alman ekonomisinde özellikle otomotiv sektöründe yaşanan emisyon değişikliğinin satışları olumsuz etkilemesi ve Brexit'ten kaynaklanan belirsizlik olduğu düşünülmektedir. Ar-Ge harcamalarının GSYH içerisindeki payı, BİT mal ithalatı ve yüksek teknoloji ihracatı oranları ile Almanya, dünya ticaretinde Avrupa ülkeleri arasında lider konumda yer almaktadır.

\section{2. Çin Örneği}

Sanayi devriminin başladığı 18. yüzyıldan bu yana meydana gelen en önemli imalat mucizelerinden birini gerçekleştiren Çin, on yıllık bir sürecin ardından 2012 yılı sonunda imalat operasyonlarında küresel bir lider ve dünyanın ikinci büyük ekonomisi konumuna gelmiştir. "Çin Malı" paradigması ile taklit ve düşük kaliteli üretim nedeniyle eleştirilen Çin, esasında kişisel bilgisayarlar, cep telefonları gibi yüksek teknoloji ürünlerin üretiminde küresel pazarda önemli bir yere sahiptir. Dolayısıyla bu teknolojileri daha da geliştirmeyi amaçlayan Çin dördüncü sanayi devrimine uyum sağlama konusunda hazır olduğunu göstermiştir (Li, 2018: 66; Liu, 2016: 53).

Bu kapsamda Çin hükümeti, dördüncü sanayi devrimine uyum sağlamak amaciyla Mart 2015'te Internet Plus eylem planının açılayarak Çin ekonomisinin ve toplumun geleneksel internetin ötesinde sayısallaştırarak ilerletmesini hedeflemiştir. Planının merkezi yönetim düzeyinde uygulanmasından Ulusal Kalkınma ve Reform Komisyonu (NDRC) sorumludur. Internet Plus, ekonomik yeniden yapılandırmayı desteklemek, insanların geçim kaynaklarını iyileştirmek ve hatta hükümet işlevlerini dönüştürmek için mobil internet, bulut bilişim, büyük veri ve nesnelerin internetini geleneksel endüstrilere entegre etmeyi amaçlamaktadır (Wübbeke vd., 2016: 20). Internet Plus, Made in China 2025 girişiminin endüstriyel ve ekonomik iyileştirme hedefi ile internetin entegre edilmesini sağlayacak bir plan olarak büyük öneme sahiptir.

Mayıs 2015'de ise Çin Devlet Konseyi, Çin malı denildiğinde akla gelen düşük kaliteli mallar önyargısını ortadan kaldırmak için "Made in China 2025" ismini verdiği planı açıklamıştır. Çin Ulusal Kalkınma ve Reform Komisyonu, Bilim ve Teknoloji Bakanlı$\breve{g}_{1}(\mathrm{MOST})$ ve Sanayi ve Bilgi Teknolojileri Bakanlığ1 (MIIT) tarafindan on yıllık bir eylem planı olarak ge- liştirilen Made in China 2025, ekonomik kalkınma için stratejik hedefler oluşturmuştur. Plan, Çin'in emek yoğun üretimden bilgi yoğun üretime endüstriyel bir dönüşüm başlatmaya, üretilen ürünlerin kalitesini iyileştirmeye, Çin'in kendi markalarını yaratmaya, ileri teknolojiler geliştirerek sağlam bir üretim kapasitesi oluşturmaya odaklanmaktadır (Li, 2018: 67).

Ekonomik kalkınmanın desteklenmesi için inovasyona dayalı büyüme stratejisi ile Çin, on yıllardır teknoloji odaklı harcamalarını artırmaya devam etmektedir. Dördüncü sanayi devriminin ortaya çıkmasının ardından Made in China 2025 stratejisi ile belirlenen hedeflere ulaşılması için her seviyedeki hükümet kuruluşlar1 Çin'in endüstriyel geleceğine büyük miktarlarda fon sağlamışlardır. Bu amaçla 2014 yılında kurulan Ulusal Entegre Devre Fonu'na 139 milyar CYN (21,8 milyar \$), 2016 yılında kurulan Gelişmiş Üretim Fonu'na ise 20 milyar CYN (3,05 milyar \$) katkı sağlanmıştır (Wübbeke vd., 2016: 7). Çip üretimi ve tasarımına yatırım yapmak ve bilgi iletişim sanayiini desteklemek amaciyla kurulan Ulusal Entegre Devre Fonu'nun ardından 2019 yılında yerli entegre devre endüstrisini beslemek ve ABD ile teknoloji açı̆̆ını kapatmak amaciyla 204,2 milyar CYN (28,9 milyar \$) değerinde yeni bir Ulusal Yarı İletken Fonu'nu kurmuştur. Gelişmiş Üretim Fonu ise endüstriyel robotlar, yeni enerjili araçlar ve raylı ulaşım sistemlerinde faaliyet gösteren şirketlerin desteklenmesi, yüksek teknoloji endüstrilerinin Batı seviyelerine yükseltilmesi ve Made in China 2025 girişiminin desteklenmesi amacıyla kurulmuştur. Çin hükümeti 2019 yılında bu fona 50 milyar CYN (7,1 milyar \$) daha finansman ayırmıştır. Merkezi olarak yönetilen bu fonlar dışında en az yirmi yerel hükümet, toplam yaklaşık 600 milyar CYN (85,2 milyar \$) değerinde yarı iletken endüstrisine yatırım araçları kurmuştur (Huifeng, 2019; Bloomberg News, 2019).

Her geçen gün ekonomisini daha da büyüten Çin, Ar-Ge yatırımlarına da son yirmi yılda büyük önem vermeye başlamıştır. Nitekim 2013'ten bu yana GSYH'sının \%2'den fazlasını Ar-Ge harcamalarına ayıran Çin'de Ar-Ge harcamalarının GSYH'ya oranı 2020 y1lında rekor seviyeye ulaşmış ve \%2,4 oranında gerçekleşmiştir (Şekil 3). Buna göre bir önceki yıla göre \%10,3 artışla 2.442,6 milyar CYN (yaklaşık 377,7 milyar \$) Ar-Ge harcaması yapılmıştır (CGTN, 2021). ABD'nin ardından Ar-Ge harcamalarında ikinci sırada yer alan Çin, harcamalarını giderek artırarak farkın daralmasını sağlamıştır. Çin'de yapılan Ar-Ge harcamalarının \%70'inden fazlası özel sektör ve yaklaşık \%20'si de kamu tarafından finanse edilmektedir. Hükümet ayrıca 2020 yılı için bilim ve teknoloji harcamalarına yaklaşık 320 milyar CYN (45 milyar \$) ayırmıştır (Chen, 2020). Dahası özel sektörde yapılacak Ar-Ge yatırımlarını teşvik etmek amacıyla önemli vergi indirimleri de sağlanmaktadır. 
Şekil 3. Çin'in AR-GE Harcamaları, BİT Mal İthalatı ve Yüksek Teknoloji İhracatı Göstergeleri (2006-2020)

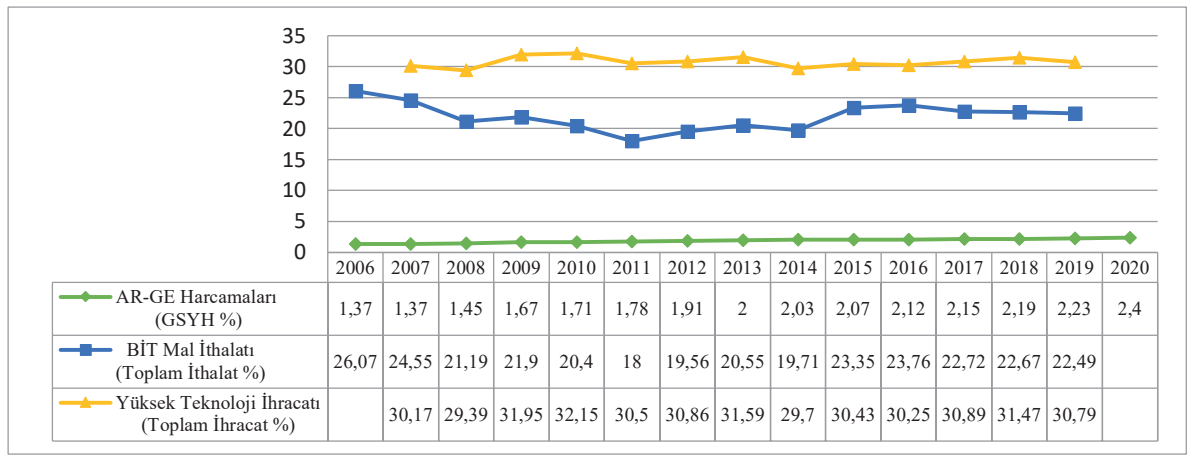

Kaynak: World Bank Data (2021), CGTN (2021)'den yararlanılarak oluşturulmuştur.

Bilgi iletişim teknolojileri ihracatı oranı 1996'dan itibaren yılda \%30 büyüyerek 2007 y1lında neredeyse 360 milyar \$’a ulaşan Çin'in BİT pazar payının 2021 yılında 8,1 trilyon \$'a (GSYH'sının \%55'i) ulaşacağ 1 tahmin edilmektedir (OECD, 2009: 90; Export.gov; 2019). Bu süreçte bilgi iletişim teknolojilerindeki gelişmelerle birlikte BİT mal ve hizmetlerin kalitesi iyileşmeye başlamış ve bu durum Çin'in rekabet gücünün artmasını sağlamıştır. Ancak toplam ithalat içerisindeki BİT mal ithalatı oranı son yıllarda önemli ölçüde dalgalanmalar göstererek 2019 yılında \%22,49 oranında gerçekleşmiştir (Şekil 3). 1990'lı yıllarda çok düşük seviyelerde yüksek teknoloji ihracatına sahip olan Çin'in, 2000'li yılların başından itibaren teknoloji yoğun ürün üreten sektörlere daha çok odaklanmaya başlaması sonucu yüksek teknoloji ihracatının toplam ihracat içerisindeki oranı genel olarak yüksek bir oranda gerçekleştirmiştir. 2019 yılında görülen BİT mal ithalatı ve yüksek teknoloji ihracatı oranlarındaki düşüşün Çin ve $\mathrm{ABD}$ arasındaki ticaret savaşı nedeniyle ortaya çıktığı düşünülmektedir.

\subsection{Amerika Birleşik Devletleri Örneği}

ABD'de Endüstri 4.0 genellikle akıllı üretim, nesnelerin interneti veya endüstriyel internet gibi terimleri kapsamakta ve büyük ölçüde özel sektör girişimleri tarafından yönlendirilmektedir. Bu doğrultuda 2012 yılı sonlarında geliştirilen Endüstriyel İnternet konsepti General Electric şirketi tarafından gündeme getirilmiştir. Endüstriyel İnternet, büyük veri analizlerini nesnelerin interneti ile birleştiren fiziksel ve dijital dünyaların sıkı bir entegrasyonu olarak görülmektedir. Bu konsept, enerji üretimi ve dağıtımı, sağlık, üretim, kamu sektörü, ulaşım ve madenciliği kapsamaktadır ve Endüstri 4.0'dan çok daha geniş bir uygulama alanına sahiptir (Rojko, 2017: 78; Kagermann vd., 2016: 12).

ABD'de dördüncü sanayi devriminin yönetildiği en önemli girişimlerden biri Endüstriyel İnternet Konsorsiyumu (Industrial Internet Consortium- IIC)'dur. IIC, en iyi uygulamaları belirleyerek, birleştirerek, test ederek ve teşvik ederek endüstriyel internetin büyü- mesini hızlandırmak için gerekli organizasyonları ve teknolojileri bir araya getirmek üzere General Electric tarafından CISCO, AT \& T, IBM ve Intel ile birlikte Mart 2014'te kurulmuştur. (Kagermann vd., 2016: 53).

Dördüncü sanayi devrimi ile dijital dönüşümü ekonomik büyüme ve rekabet gücünün artması olarak gören ABD'de dönüşüm süreci büyük oranda özel sektör tarafından yürütülmektedir. Hükümet ise geliştirdiği politikalar, yüksek AR-GE harcamaları ve artan destek ve teşviklerle süreci desteklemektedir. Bu destekler, 2014 yılında faaliyete geçirilen ve Manufacturing USA olarak da adlandırılan Ulusal İmalat İnovasyon A ̆̆ (NNMI) bünyesinde kurulan 14 imalat enstitüsü ile sağlanmaktadır. Bu enstitüler, ABD endüstrisinden kuruluşlar, üniversiteler ve Ticaret Bakanlığg (DOC), Savunma Bakanlığı (DoD) ve Enerji Bakanlığı (DOE) arasında kamu-özel ortaklığı ile oluşturulmuştur. Tablo 1'de bu enstitülerin kuruluş yılları, bulundukları merkezler, geliştirilen teknolojiler, destekleyen federal kurumlar ve bu kurumlar tarafından sağlanan finansman tutarları ve süreleri gösterilmektedir.

Manufacturing USA ağı tarafından hazırlanan yıllık raporlara göre programı kapsamında yürütülen enstitüler için 2016 yılında toplam yaklaşık 333,81 milyon \$ harcama yapılmış ve bu harcamaların yaklaşık 144,9 milyon \$'1 federal fonlar ile finanse edilmiştir. 2017 yılında 298,5 milyon \$ olan toplam enstitü harcamalarının 120,7 milyon \$'1 ve 2018 yılında 496,9 milyon \$ olan toplam enstitü harcamalarının ise 183,4 milyon \$'1 federal fonlar ile finanse edilmiştir. Ancak 2019 ve 2020 yılları için henüz yıllık rapor hazırlanmamıştır. $\mathrm{Bu}$ fonlar, teknoloji araştırma ve geliştirme projeleri, eğitim ve işgücü yetiştirme çalışmaları, tesis ve üretim ekipmanı satın alma, enstitü operasyonları gibi sermaye yoğun faaliyetler için harcanmıştır (Manufacturing USA, 2019: 15).

ABD'de, dördüncü sanayi devrimine yönelik yapılan çalışmalar ve harcamalar sonucunda 2016 yılında imalat sektörü yaklaşık 2 trilyon $\$$ değere ulaşmıştır. Bu miktar ABD GSYH' sının \%12'sini oluşturmaktadır. Özellikle imalat sektörünü canlandırmak için çaba 
Tablo 1. NNMI Programı Kapsamında Kurulan Enstitüler ve Federal Kurumlar Tarafından Sağlanan Finansman Tutarları

\begin{tabular}{|c|c|c|c|c|c|}
\hline $\begin{array}{l}\text { Kuruluş } \\
\text { Yılı }\end{array}$ & Enstitü & Teknoloji & $\begin{array}{l}\text { Finansman } \\
\text { Kurumu }\end{array}$ & Merkez & $\begin{array}{l}\text { Federal } \\
\text { Finansman }\end{array}$ \\
\hline $\begin{array}{c}\text { Ağustos } \\
2012\end{array}$ & $\begin{array}{l}\text { Ulusal Katmanlı Üretim İnovasyon } \\
\text { Enstitüsü (America Makes) }\end{array}$ & $\begin{array}{l}\text { Katmanlı Üretim, Üç } \\
\text { Boyutlu Bask1 }\end{array}$ & $\mathrm{DoD}$ & Youngstown, Ohio & $\begin{array}{l}65 \text { Milyon \$ } \\
(7 \text { Y11) }\end{array}$ \\
\hline Şubat 2014 & Dijital Üretim Enstitüsü (MxD) & $\begin{array}{l}\text { Dijital Üretim ve } \\
\text { Tasarım }\end{array}$ & DoD & Chicago, Illinois & $\begin{array}{l}83 \text { Milyon } \$ \\
(5 \text { Yil })\end{array}$ \\
\hline Şubat 2014 & $\begin{array}{c}\text { Yarın için Hafif Yenilikler Enstitüsü } \\
\text { (LIFT) }\end{array}$ & $\begin{array}{c}\text { Gelişmiş Hafif ve } \\
\text { Modern Metal Üretimi }\end{array}$ & DoD & Detroit, Michigan & $\begin{array}{l}70 \text { Milyon } \$ \\
(5 \text { Yil })\end{array}$ \\
\hline Ocak 2015 & $\begin{array}{l}\text { Yeni Nesil Güç Elektroniği Üretim } \\
\text { İnovasyon Enstitüsü (PowerAmerica) }\end{array}$ & $\begin{array}{l}\text { Geniş Bant Aralı̆ğ Güç } \\
\text { Elektroniği Üretimi }\end{array}$ & DOE & $\begin{array}{l}\text { Raleigh, North } \\
\text { Carolina }\end{array}$ & $\begin{array}{l}70 \text { Milyon } \$ \\
(5 \text { Yil })\end{array}$ \\
\hline $\begin{array}{c}\text { Haziran } \\
2015\end{array}$ & $\begin{array}{c}\text { İleri Kompozit Üretim İnovasyonu } \\
\text { Enstitüsü (IACMI) }\end{array}$ & Kompozit Malzemeler & DOE & $\begin{array}{l}\text { Knoxville, } \\
\text { Tennessee }\end{array}$ & $\begin{array}{l}70 \text { Milyon } \$ \\
(5 \text { Yil })\end{array}$ \\
\hline $\begin{array}{l}\text { Temmuz } \\
2015\end{array}$ & $\begin{array}{c}\text { Amerikan Entegre Fotonik Üretim } \\
\text { Enstitüsü (AIM) }\end{array}$ & $\begin{array}{l}\text { Fotonik Entegre } \\
\text { Ekosistemler }\end{array}$ & DoD & $\begin{array}{l}\text { Roscheser, } \\
\text { New York }\end{array}$ & $\begin{array}{l}110 \text { Milyon \$ } \\
\text { (5 Y11) }\end{array}$ \\
\hline $\begin{array}{c}\text { Ağustos } \\
2015\end{array}$ & $\begin{array}{c}\text { Amerika'nın Esnek Hibrid Elektronik } \\
\text { Üretim Enstitüsü (NextFlex) }\end{array}$ & Esnek Hibrid Elektronik & $\mathrm{DoD}$ & $\begin{array}{l}\text { San Jose, } \\
\text { California }\end{array}$ & $\begin{array}{l}75 \text { Milyon } \$ \\
\left(5 Y_{1} 1\right)\end{array}$ \\
\hline Nisan 2016 & $\begin{array}{c}\text { Amerika'nın Gelissmiş Fonksiyonel } \\
\text { Kumaşları Enstitüsü (AFFOA) }\end{array}$ & Geliştirilmiş Tekstil & DoD & $\begin{array}{l}\text { Cambridge, } \\
\text { Massachusetts }\end{array}$ & $\begin{array}{l}75 \text { Milyon \$ } \\
(5 \text { Yil) }\end{array}$ \\
\hline Aralık 2016 & $\begin{array}{l}\text { İleri Rejeneretif Üretim Enstitüsü } \\
\text { (BioFabUSA) }\end{array}$ & $\begin{array}{l}\text { Rejeneretif Tip, Doku } \\
\text { Mühendisliği }\end{array}$ & DoD & $\begin{array}{l}\text { Manchester, New } \\
\text { Hampshire }\end{array}$ & $\begin{array}{l}80 \text { Milyon } \$ \\
(5 \text { Y11) }\end{array}$ \\
\hline Ocak 2017 & İleri Robotik Üretim Enstitüsü (ARM) & $\begin{array}{c}\text { İnsan İşbirlikçi Robotik, } \\
\text { Yapay Zekâ, } \\
\text { Otomasyon }\end{array}$ & $\mathrm{DoD}$ & $\begin{array}{l}\text { Pittsburg, } \\
\text { Pennsylvania }\end{array}$ & $\begin{array}{l}80 \text { Milyon } \$ \\
(5 \text { Y } 11)\end{array}$ \\
\hline Ocak 2017 & $\begin{array}{c}\text { Temiz Enerji Akıllı Üretim İnovasyon } \\
\text { Enstitüsü (CESMII) }\end{array}$ & Ak1llı Üretim & DOE & $\begin{array}{l}\text { Los Angeles, } \\
\text { California }\end{array}$ & $\begin{array}{l}70 \text { Milyon \$ } \\
(5 \text { Yil })\end{array}$ \\
\hline Mart 2017 & $\begin{array}{l}\text { Ulusal Biyofarmasötik Üretiminde } \\
\text { Yenilik Enstitüsü (NIIMBL) }\end{array}$ & Biyofarmasötik Üretim & DOC & Newark, Delaware & $\begin{array}{l}70 \text { Milyon \$ } \\
(5 \text { Y11 })\end{array}$ \\
\hline Mart 2017 & $\begin{array}{l}\text { Süreç Yoğunlaştırma Dağitımında } \\
\text { Hızlı İlerleme Enstitüsü (RAPID) }\end{array}$ & $\begin{array}{c}\text { Temiz Üretim İçin } \\
\text { Modüler Kimyasal } \\
\text { Proses Yoğunlaştırma }\end{array}$ & $\mathrm{DOE}$ & $\begin{array}{l}\text { New York, New } \\
\text { York }\end{array}$ & $\begin{array}{l}70 \text { Milyon \$ } \\
(5 \text { Y11 })\end{array}$ \\
\hline Mayıs 2017 & $\begin{array}{l}\text { Gömülü Enerjiyi ve Emisyonları } \\
\text { Azaltma Enstitüsü (REMADE) }\end{array}$ & $\begin{array}{c}\text { Temiz Enerji ile } \\
\text { Sürdürülebilir Karbon } \\
\text { Emisyonu ve Üretimini } \\
\text { Azaltma }\end{array}$ & DOE & $\begin{array}{l}\text { Rochester, New } \\
\text { York }\end{array}$ & $\begin{array}{l}70 \text { Milyon } \$ \\
(5 \text { Yil })\end{array}$ \\
\hline
\end{tabular}

Kaynak: Manufacturing USA (2019) kaynağından yararlanılarak oluşturulmuştur.

sarf eden ABD, bu hedefe ulaşmak için dördüncü sanayi devrimi teknolojilerini yakından takip ederek başarıla uygulamaktadır (World Economic Forum ve A.T. Kearney, 2018: 16).

Dünyanın en yüksek Ar-Ge harcamalarına sahip olan ABD'de Ar-Ge harcamalarının GSYH'ya oranı genel olarak sabit bir seyir izlemiş ve 2018 yılında \%2,94 oranında gerçekleşmiştir. 2018 yılında toplam 606,1 milyar \$ olarak gerçekleşen Ar-Ge harcamalarının 2019 yılında 656 milyar \$’a ulaşması beklenmektedir. \%2,94 olan bu Ar-Ge finansmanının kaynağını \%2,07 oranında özel sektör oluştururken yalnızca \%0,63'ü federal hükümet oluşturmaktadır (Boroush, 2021: 1-3).
2007 yılında \%13,46 BİT mal ithalatı oranı ve 273 milyar \$ ile $A B D$, BİT ürünlerinin en büyük ithalatçısı olmuştur (OECD, 2009: 90). 2008 yılında küresel kriz nedeniyle BİT mal ithalatı oranı düşmüş daha sonra 2017'ye kadar genel olarak yükselme eğilimi gösterse de tekrar düşerek 2019 yılında toplam ithalat içindeki BİT mal ithalatı \%12,93 oranında gerçekleşmiştir. 2007 yılından sonra sürekli olarak düşen toplam ihracat içindeki yüksek teknoloji ihracatı oranları ise 2012 y1lından sonra tekrar artmaya başlamış ancak 2017 y1lında keskin bir düşüş yaşamış ve 2019 yılında \%18,93 oranında gerçekleşmiştir (Şekil 4). Bu keskin azalışa 2017 yılında ABD'de yaşanan başkanlık seçimleri ve

Şekil 4. ABD’nin AR-GE Harcamaları, BİT Mal İthalatı ve Yüksek Teknoloji İhracatı Göstergeleri (2006-2019)

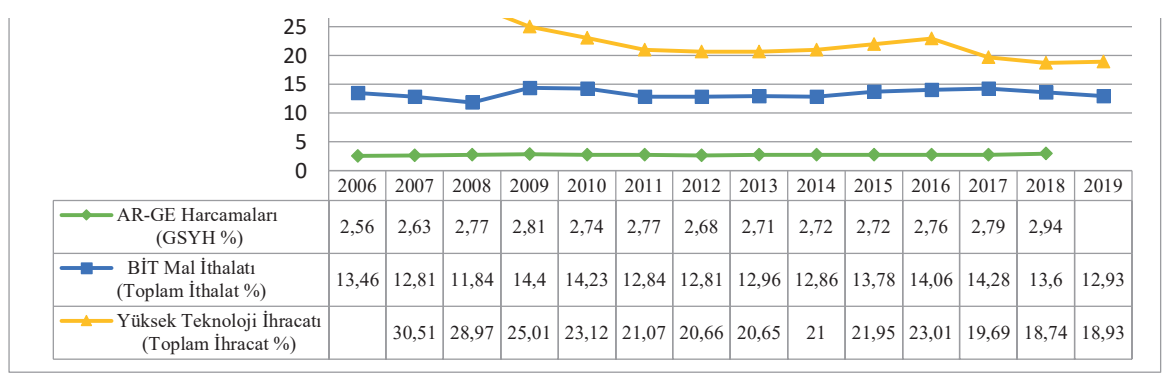

Kaynak: World Bank Data (2021), Boroush (2021: 3)'den yararlanılarak oluşturulmuştur. 
Çin ile ABD arasındaki ticaret savaşlarının neden olduğu düşünülmektedir.

\section{TÜRKİYE'DE SANAYİLEŞME, ENDÜSTRİ 4.0 VE KAMU HARCAMALARI}

Sanayi devriminin ortaya çıktığı 18. yüzyıl sonlarından itibaren gerek Osmanlı Devleti'nde gerek Cumhuriyet'in ilk yıllarında sanayileşmenin önemi kavranmış, gerekli atılımlar gerçekleştirilmiş ve önemli kamu yatırımları yapılmıştır. Bu kapsamda Osmanlı Devleti'nde fabrikalar inşa edilmiş, sanayileşmenin temel sorunlarından olan vasıflı işgücü ve sermaye yetersizliği aşılmıştır. Ancak fabrikalardaki teknolojilerin yenilenememesi ve yeterli ve kaliteli hammaddenin temin edilememesi istenen başarının elde edilmesini engellemiştir (Kal'a 2003: 253).

Cumhuriyet'in ilanının ardından da sanayileşmeye büyük önem verilmiş ve bu kapsımda 1930'lu yıllarda Beş Yıllık Sanayi Planları, 1963 yılından itibaren de Beş Yıllık Kalkınma Planları hazırlanmış ve uygulanmıştır. Bu planlarda genel olarak sanayileşmenin kalkınmanın temel kaynağı olduğuna vurgu yapılmış ve bu çerçevede hedefler belirlenmiştir. Ancak Osmanlı Devleti'nde olduğu gibi teknoloji ve girdi eksikliği sorunlarının giderilememesi Türkiye'nin de sanayileşmesinin önünde engel oluşturmuştur. TÜBİTAK bu kapsamda dünyadaki dönüşüme uyum sağlamak amacıyla Türk Bilim Politikası 1983-2003 ve Türk Bilim ve Teknoloji Politikası: 1993-2003 politikalarını geliştirmiştir. Bu politikalarla da genel olarak Türkiye'nin gelişmiş ve sanayileşmiş ülkeler arasında yer alan, bilim ve teknolojiye katkı sağlayarak yeni teknolojiler üretebilen ve geliştirebilen ülkeler arasında yer alması amaçlanmış ve buna yönelik politikalar oluşturulmuştur. Yedinci Kalkınma Planı içinde yer alan Bilim ve Teknoloji Atılım Projesi (1995) ile Türkiye'nin bilim ve teknoloji yeteneğinin yükseltilmesi amaçlanmıştır. 2000'li yıllarda hazırlanan Vizyon 2023: Bilim ve Teknoloji Stratejileri ile Türkiye Sanayi Strateji Belgeleri ile de yüksek katma değere sahip yüksek teknoloji üretiminin yapılması hedeflenmiştir.

Osmanlı Devleti'nden almış olduğu sanayi mirası ile Cumhuriyet'in kuruluş yıllarından günümüze kadar ekonomik kalkınmanın kilit noktasının sanayileşme olduğunun farkında olan Türkiye, sanayiye yönelik hazırlanan her plan, politika ve strateji belgesinde bu öneme vurgu yapmiştır. Bu belgelerinin her biri Türkiye'nin sanayileşmesinin ve teknolojik ilerlemesinin gerçekleştirilebilmesini sağlayabilecek belgeler olarak hazırlanmıştır. Ancak hazırlanan bu belgelerin bir kıs$\mathrm{m} 1$ siyasi istikrarsızlıklar ve krizler gibi sorunlar nedeniyle uygulanamamıştır. Türkiye'nin bu plan, politika ve strateji belgeleri ile belirlenen hedef ve uygulamaların her birini kararlılıkla yerine getirmiş olması du- rumunda, bugün çok daha farkl1, teknoloji yoğun ve gelişmiş bir sanayi görünümüne sahip olabileceğini söylemek mümkündür.

Türkiye tüm sanayileşme çabalarına rağmen bugün Endüstri 2.0 ile Endüstri 3.0 arasında bir konumda yer almaktadır (Eğilmez, 2019: 191). Bu nedenle 2011 yılında hız kazanan dördüncü sanayi devrimi ile yakından ilgilenmektedir. Ancak henüz robotik teknolojilerden faydalanamadığı ve üretimde otomasyonu sağlayamadığı için öncelikle üretimde otomasyonu artırması, sonra sensör, uyarıcı vb. teknolojiler aracıl1ğıyla desteklemesi ve daha sonra da siber fiziksel sistemlere geçmesi gerektiği konunun uzmanları tarafından vurgulanmaktadır. Bu teknolojilerin geliştirilmesi için de Ar-Ge kabiliyetini artıracak, endüstriyi işbirliğine teşvik edecek büyük adımlar atması gerekmektedir. Zira bu devrimi de kaçırması, gelişmiş ülkeler ile arasındaki farkın giderek daha fazla açılmasına neden olacaktır (Özhan, 2016: 24-25).

Bu kapsamda Türkiye'nin dördüncü sanayi devrimine uyum sağlama serüveninde Bilişim Vadisi'nin kurulması, 29. Bilim ve Yüksek Teknoloji Kurulu Toplantısı (BTYK) kararları, Dijital Türkiye Yol Haritası'nın hazırlanması ve Dijital Dönüşüm Ofisi'nin kurulması olmak üzere önemli yapı taşları bulunmaktadır. Bilişim Vadisi 2012 yılında kurulmakla birlikte doğrudan dördüncü sanayi devrimine uyum sağlamak amaciyla yapılan ilk çalışma Şubat 2016'ta gerçekleştirilen 29. Bilim ve Teknoloji Yüksek Kurulu toplantısıdır. Bu toplantıda genel olarak Türkiye'nin dördüncü sanayi devrimindeki konumunun güçlendirilmesi, dijital dönüşümün hızlandırılması ve küresel rekabet gücünün artırılmasını sağlayacak yüksek teknoloji içeren akıllı üretim sistemlerine geçilmesine yönelik kararlar alınmıştır. Bu çerçevede dördüncü sanayi devriminin temel bileşenlerinde (büyük veri, yapay zekâ, bulut bilişim vb.) yetkinlik kazanılmasına yönelik Ar-Ge harcamalarının artırılması ve bu teknolojilerin yerli firmalar tarafından üretilmesini sağlayacak teşvik ve destek sistemlerinin gözden geçirilmesi ve geliştirilmesi amaçlanmıştır (BTYK, 2016).

BTYK toplantısında alınan kararlar kapsamında 2016 yılında TÜBİTAK tarafından Yeni Sanayi Devrimi: Akıllı Üretim Sistemleri Yol Haritası hazırlanmış ve dördüncü sanayi devrimine yönelik hazırlıklar yapılmaya başlanmıştır. Hazırlanan yol haritası ile Dijitalleşme, Etkileşim ve Geleceğin Fabrikaları olmak üzere 3 teknoloji grubunda 8 kritik teknoloji, Türkiye'nin küresel seviyeyi yakalaması ve üzerine geçmesi amaciyla 10 stratejik hedef ve 29 kritik ürün belirlenmiştir (TÜBİTAK, 2016: 5-6). 2016 yılı sonlarında ise farklı kurum ve kuruluşlarla yürütülen Endüstri 4.0 çalışmalarını tek bir çatı altında toplamak ve dijital dönüşümün sağlanması için iş birliğini güçlendirmek amacıyla Bilim, Sanayi ve Teknoloji Bakanlığı tarafından Almanya'nın Endüstri 4.0 Platformu'na benzer 
Sanayide Dijital Platformu kurulmuştur.

Türkiye'de dördüncü sanayi devrimine katkı sağlayacak kamu destekli gelişmeler;

\subsection{Bilișim Vadisi}

ABD'nin Silikon Vadisi'nden esinlenerek 16.08.2012 tarihinde kurulan Bilişim Vadisi (Muallimköy Teknoloji Geliştirme Bölgesi), Türkiye'nin dijital dönüşümünü sağlamayı hedefleyen en büyük tematik teknoloji geliştirme bölgesidir. Bilişim Vadisi, Sanayi ve Teknoloji Bakanlığı himayesinde Kocaeli'de kurulmuştur. Bilişim Vadisi'nin paydaşları TÜBİTAK, Gebze Teknik Üniversitesi, Kocaeli Üniversitesi, Türk Patent ve Marka Kurumu, Türk Standartları Enstitüsü, TOSB, KOSGEB, İstanbul Ticaret Odası, Kocaeli Sanayi Odası, Kocaeli Ticaret Odası, Gebze Ticaret Odası, İstanbul Sanayi Odası, Kocaeli Büyükşehir Belediyesi ve İzmir Yüksek Teknoloji Enstitüsü'dür.

Bilişim Vadisi'nin bilişim ve ilgili sektörlerin gelişimini sağlaması, bu sektörlerdeki firmalar için bir cazibe merkezi olması ve sektörün bütün alt dalları ile işbirliği içerisinde çalışabileceği bir merkez üs olması hedeflenmektedir. Ayrıca Microsoft, Huawei gibi büyük firmalarla Türkiye'deki firmaların işbirliği kurmasını sağlayan bir teknoloji transfer merkezi olması amaçlanmaktadır (MARKA ve Bilişim Vadisi, 2019: 31-49). Bu kapsamda, başta bilişim teknolojileri olmak üzere yazılım, robotik, telekomünikasyon ve elektrik- elektronik vb. alanlarda AR-GE çalışmaları yürüten bütün firmalara ev sahipliği yapmaya hazırdır.

Bilişim Vadisi'nde faaliyet gösteren firmalara önemli vergisel avantajlar sağlanmaktadır. Bu avantajlar, firmaların damga vergisinden muaf tutulması ve 12 yıl süreyle \%100 KDV muafiyetine tabi olması, çalışanlara \%100 gelir vergisi indirimi uygulanması ve personelin sigorta primlerinin $\% 50$ 'sinin devlet tarafından karşılanması ve bu firmaların 2023 yılına kadar yürüttükleri Ar-Ge ve teknoloji geliştirme çalışmaları nedeniyle gelir ve kurumlar vergisinden muaf tutulması şeklindedir (MARKA ve Muallimköy Teknopark A.Ş., 2013: 5).

\subsection{Dijital Türkiye Yol Haritası}

Türkiye'nin Almanya'daki “Industrie 4.0" veya Çin'deki "Made in China 2025" benzer dördüncü sanayi devrimi girişimi ise 2018 yılında Bilim, Sanayi ve Teknoloji Bakanlığı tarafından hazırlanan Dijital Türkiye Yol Haritası ile başlatılmıştır. Yol haritasının hazırlanma sürecinde ülke sanayiinin yüksek teknoloji üretim kapasitesini artırmak, yerli ve katma değeri yüksek ürünlerin küresel pazarlara entegre edilmesini sağlamak amaciyla Sanayide Yüksek Teknolojiye Geçiş Programı'nı başlatmış ve bu kapsamda sanayi zirveleri düzenlemiştir. Türkiye gibi gelişmekte olan bir ülke için oldukça maliyetli olan dijitalleşme süre- cinin devlet desteği olmaksızın gerçekleştirilmesi zordur. Bu nedenle program kapsamında devlet, kamuda yerli malı alımına yönelik destekler, araştırma geliştirme ve tasarım faaliyetlerine yönelik damga vergisi istisnası, vergi indirimi, sigorta prim desteği gibi destekler, endüstri bölgelerinin desteklenmesi ve teşviki ve sanayi işbirliği programları ile Türkiye'nin dijitalleşme sürecini hızlandırmayı amaçlamaktadır (BSTB, 2018b: 13-17).

Sanayide Yüksek Teknolojiye Geçiş Programı sonrasında 10 yıllık bir perspektifte hazırlanan Dijital Türkiye Yol Haritasının ilk iki yılı kısa vadede gerçekleştirilecek eylemlerden ve imalat sanayinde dijital dönüşüme ivme kazandıracak somut adımlardan oluşmaktadır. 3-5 yıllık orta vadede, başta odak sektörlerde ve seçili teknolojilerde olmak üzere Türkiye'nin dijitalleşme konusundaki açığını kapatmaya odaklanılmaktadır. 6-10 yıllık uzun vadede ise dijitalleşme sürecinde belirli sektör ve teknolojilerde bölgesel veya küresel lider olmak amaçlanmaktadır. $\mathrm{Bu}$ yol haritası yalnızca sanayinin dijital dönüşümü olarak değil aynı zamanda toplumun da dönüşümünü hedefleyen bir program olarak hazırlanmıştır. Bu hedefler doğrultusunda hazırlanan yol haritasının altı temel bileşeni bulunmaktadır. Bu bileşenler "insan, teknoloji, altyapı, tedarikçiler, kullanıcılar ve yönetişimdir" (BSTB, 2018a: 17).

İlk bileşen olan ve dijitalleşme sürecini hem yöneten hem de bu süreçten etkilenen insan bileşeni kapsamında nitelikli işgücünün yetiştirilmesi ve mevcut işgücünün bu sürece adapte edilmesi hedeflenmektedir. Teknoloji bileşeni ile dijital dönüşümün tamamlanmasını sağlayacak olan teknoloji altyapısının oluşturulması, altyapı bileşeni ile dijitalleşme sürecinde sanayiin ihtiyaç duyacağı veri altyapısının oluşturulması amaçlanmaktadır. Tedarikçiler bileşeni ile ulusal teknoloji tedarikçilerinin desteklenerek yetkinliklerinin geliştirilmesi, kullanıcılar bileşeni ile işletmelerin (kullanıcıların) dijital teknolojileri daha etkin bir şekilde kullanımının sağlanması ve yönetişim bileşeni ile diğer beş bileşen kapsamında belirlenen hedefler doğrultusunda dijital dönüşüm sürecini yönlendirecek ve paydaşlar arasında koordinasyonu sağlayacak etkin bir yönetişim altyapısının oluşturulması amaçlanmaktadır.

Belirlenen hedeflere ulaşılması ve dijital dönüşüm sürecinin başarılı bir şekilde tamamlanması halinde, Endüstri 4.0 aracılığıyla kazanılacak rekabet avantajı, sanayi üretiminde yıllık yaklaşık \%3'e kadar bir artış yaratacaktır. Bu büyüme Türkiye GSYH'sında \%1 ve üzeri ek bir büyüme ve 150-200 milyar TL değerinde ek gelir sağlayarak ekonomik büyümeye katkı sağlayacaktır (TÜSİAD ve BCG, 2016: 14). Yol haritası kapsamında belirlenen hedeflere ulaşılması ve dijital teknolojilerin geliştirilmesi için ihtiyaç duyulan finansman kamu tarafindan AR-GE harcamaları, des- 
tekler ve teşvikler yoluyla sağlanmaktadır.

\subsection{Dijital Dönüşüm Ofisi}

Dördüncü sanayi devrimi ile gelişmeye başlayan teknolojilerin ardından Türkiye'de farklı kurumlarca ayrı ayrı yürütülen e-devlet uygulamalarının, yapay zekâ, büyük veri, siber güvenlik gibi çalışmalarının tek bir çatı altında toplanması ve kamu sektörünün dijital dönüşümünün hızlandırılması amacıyla 10 Temmuz 2018 tarihinde Cumhurbaşkanlığ ${ }_{1}$ Dijital Dönüşüm Ofisi kurulmuştur. 30474 sayılı Resmi Gazete (2018)'de, 1 Sayılı Cumhurbaşkanlığı Kararnamesi kapsamında kurulan Dijital Dönüşüm Ofisi'nin görevleri "kamunun dijital dönüşümüne öncülük etmek, kamuda dijital dönüşüm yol haritası hazırlamak, kamu, özel sektör, üniversiteler ve sivil toplum kuruluşlarını arasındaki işbirliğini geliştirerek dijital dönüşüm ekosistemini oluşturmak ve bunların bu sürece katılımını teşvik etmek, kamuda büyük veri, yapay zekâ, siber güvenlik çalışmalarına öncülük etmek ve koordinasyon sağlamak, yerli ve milli dijital teknolojilerin kamuda kullanımının artırılmasına yönelik projeler geliştirmek" şeklindedir. Dijital Dönüşüm Ofisi'nin teşkilat yapısı sekiz daire başkanlığı ve hukuk müşavirliğinden oluşmaktadır. Bu başkanlıklar, Dijital Dönüşüm Koordinasyon Dairesi, Dijital Teknolojiler, Tedarik ve Kaynak Yönetimi Dairesi, Dijital Uzmanlık, İzleme ve Değerlendirme Dairesi, Siber Güvenlik Dairesi, Büyük Veri ve Yapay Zekâ Uygulamaları Dairesi, Uluslararası İlişkiler Dairesi, Bilgi Teknolojileri Dairesi, Yönetim Hizmetleri Dairesi Başkanlıkları olarak hizmet vermektedir.

Sanayi ve Teknoloji Bakanlığı ile koordineli olarak çalışan Dijital Dönüşüm Ofisi, kamu kurumlarının dijital dönüşümünü sağlamaya çalışmakta ve böylece kamu hizmetlerinin hızlandırılıp bürokrasi süreçlerinin azaltılmasını hedeflemektedir. Bu kapsamda ilk olarak eğitim altyapısını geliştirmeye odaklanılması ve üniversitelerde dijital teknolojilerin geliştirilmesine yönelik programların artırılması, 30.000'e yakın öğrencinin dijital teknoloji alanında doktora yapması, dijital yetkinliklere sahip işgücünün sanayi ile buluşturulması için özel teşvikler sağlanması gibi çalışmalar yürütülmektedir (Yankın, 2019: 16).

2019 yılında merkezi yönetim bütçesinden hazine yardımları kapsamında Dijital Dönüşüm Ofisi'nin başlangıç ödeneği 70 milyon TL olarak belirlenmiştir. 2020 yılında bu miktar 80.5 milyon TL, 2021 yılında ise 96,6 milyon TL olarak belirlenmiştir (SBB, 2021a: 381). Ofisin henüz kısa bir süre faaliyet göstermesi ve faaliyet raporu yayınlamaması nedeniyle yapılan harcamaların etkinliğinin ve verimliliğinin değerlendirilmesi zordur.

\subsection{Dördüncü Sanayi Devrimi Kapsamında Türki- ye'de Kamu Harcamaları}

Türkiye'nin mevcut sanayi teknoloji ekosistemi ile küresel teknolojik dönüşümü yakalayabilmesi için belirli alanlarda gelişim sağlaması gerekmektedir. ArGe yatırımları bu gelişimin sağlanması için gereken en önemli noktalardan biridir. Artan devlet teşvikleri, dışa açılmanın vermiş olduğu rekabet baskısının etkisi ve hazırlanan politikalar ve stratejiler ile Türkiye'de Ar-Ge alanlarına tahsis edilen kaynaklar ve bu alanlarda istihdam edilen personel sayıları son zamanlarda ciddi bir artış göstermiştir. Bu açıdan Türkiye'de kamu kesiminin Ar-Ge'ye ilgisi de her geçen gün artmaktadır (Dursun ve Şengül, 2018: 71; Gür vd., 2017: 144). Nitekim Cumhuriyet'in kuruluş yıllarından beri Ar-Ge harcamalarının artırılmasını hedeflemekte ve hazırlanan plan, politika ve stratejilerde bu hedefe yer vermektedir. Bu süreçte 2006 yılında \%0,56 olan ARGE harcamaları oranı belirlenen hedeflere ulaşılmasa da genel olarak artış eğilimi sergileyerek 2019 yılında \%1,06 olarak gerçekleşmiştir (Şekil 5). Ancak bu oranların diğer ülke oranları ile karşılaştırıldığında yeterli olmadığı görülmektedir.

Dijital Türkiye Yol Haritasının uygulanmaya başlandığ 2018 yılında yapılan 38 milyar 534 milyon TL ArGe harcamasının 13 milyar 24 milyon TL'si merkezi yönetim bütçesinden karşılanmıştır. 2019 yılında ise bu miktar \%14,6 artışla 14,92 milyon TL'ye ulaşmıştır. Buna göre GSYH içindeki Ar-Ge harcamaları oranının \%0,35'i merkezi yönetim bütçesinden karşılanmıştır (TÜİK, 2020).

Şekil 5'te, Türkiye'nin Ar-Ge harcamaları, bilgi iletişim teknolojileri mal ithalatı ile yüksek teknoloji ihracatı oranları gösterilmektedir. Ele alınan ülkelere kıyasla çok düşük oranlarda kalan bu göstergelerden BİT mal ithalatı oranı, son dönemlerde döviz kurlarında meydana gelen artışlar nedeniyle önemli ölçüde düşüş yaşamıştır. Son yıllarda dalgalanmalar gösteren yüksek teknoloji ithalatı oranı ise 2019 yılında \%3,04 olarak gerçekleşmiştir. Mevcut veriler ele alındığında Türkiye'nin dijitalleşme hedeflere en kısa zamanda ulaşabilmesi ve teknoloji altyapısını oluşturabilmesi için BİT mal ithalatının desteklenmesi, aynı zamanda küresel rekabette söz sahibi olabilmesi için de yüksek teknoloji ihracatı oranlarını artırması büyük önem arz etmektedir.

Türkiye'de dijital dönüşüm sürecinin gelişiminde kamu girişimleri önemli bir yer tutsa da yeterli değildir. Çünkü özel sektörün dijitalleşemediği bir ekonomide dördüncü sanayi devrimi ile yaşanan küresel dönüşümü yakalamak oldukça zor olacaktır. Bu sebeple Türkiye'de özel sektörün teşvik edilmesi ve özel sektörün gerçekleştireceği girişimlere altyapı oluşturulması için her geçen yıl daha fazla destek ve teşvik ödeneği tahsis edilmektedir. Bu destekler ve teşvikler 
Şekil 5. Türkiye'nin AR-GE Harcamaları, BİT Mal İthalatı ve Yüksek Teknoloji İhracatı Göstergeleri (2006-2019)

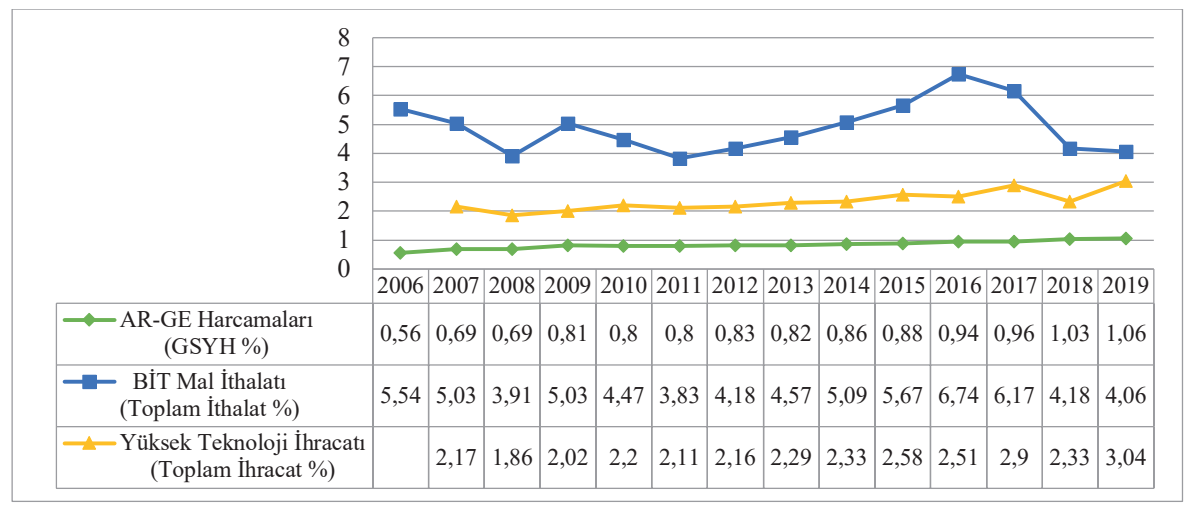

Kaynak: TÜİK (2020), World Bank Data (2021)'den yararlanılarak oluşturulmuştur.

yoluyla vazgeçilen vergiler de vergi harcaması yoluyla harcamaları artırmaktadır.

Türkiye'de bilim, sanayi, teknoloji ve bilgi iletişim alanlarında faaliyet gösteren, TÜBİTAK, Bilgi Teknolojileri ve İletişim Kurumu (BTK) ve Sanayi ve Teknoloji Bakanlığı hazırladıkları plan ve projeler, gerçekleştirdikleri faaliyet ve çalışmalar ile doğrudan ve dolaylı olarak Endüstri 4.0'ın gelişimine katkı sağlamaktadırlar. Kuruluşundan bu yana Türkiye'nin sanayileşmesini geliştirmek ve hızlandırmak amacıyla faaliyet gösteren Sanayi ve Teknoloji Bakanlığı, bu çerçevede sanayi, bilim ve teknoloji alanlarının gelişimine yönelik faaliyetleri ve yatırımları desteklemektedir. Türkiye'nin Ar-Ge, inovasyon, bilim ve teknoloji alanlarında faaliyet gösteren önemli kuruluşlar arasında ilk sırada yer alan TÜBİTAK, bu faaliyetlerle önemli destekler sunmakta ve GSYH içindeki ArGe harcamaları oranının artmasında önemli katkılar sağlamaktadır. BTK ise, doğrudan dördüncü sanayi devriminin gelişimine yönelik faaliyet göstermemekle birlikte, bilgi ve iletişim teknolojileri, telekomünikas- yon, siber güvenlik gibi alanlarda faaliyet göstererek Türkiye'nin dijital teknoloji altyapısının oluşturulmasına dolaylı olarak katkı sağlamaktadır.

Bu kurumların yapmış olduğu harcamalar, dijital teknolojilerin geliştirilmesi ve Türkiye'nin dijital dönüşümünün tamamlanmasına yönelik olarak gerçekleştirildiği için dördüncü sanayi devrimi kapsamında yapılan kamu harcamaları arasında değerlendirilebilmektedir. Bu kurumların dördüncü sanayi devriminin ortaya çıktığı 2011 yılından itibaren yapmış olduğu harcamalar Tablo 2'de gösterilmektedir.

Bahsi geçen kurumlar, bilim, sanayi ve teknoloji alanlarında harcama yaparak doğrudan ya da dolaylı şekilde dördüncü sanayi devrimine yönelik harcama yapmaktadırlar. Bu kurumların dışında pek çok kamu kurumu ve belediye de hizmet kalitesini iyileştirmek ve erişimi kolaylaştırmak için dijital teknolojilerin geliştirilmesine yönelik "Belediye 2.0" ve benzeri çalışmalar ve harcamalar yapmaktadır. Tüm bu harcamaların Türkiye'nin dijital teknoloji altyapısının

Tablo 2. Merkezi Yönetim, Sanayi ve Teknoloji Bakanlığı, TÜBİTAK ve BTK'nın 2011-2019 Bütçe Giderleri (Bin TL)

\begin{tabular}{|c|c|c|c|c|}
\hline & $\begin{array}{c}\text { Merkezi } \\
\text { Yönetim Bütçe } \\
\text { Giderleri }\end{array}$ & $\begin{array}{c}\text { Sanayi ve } \\
\text { Teknoloji } \\
\text { Bakanlığı }\end{array}$ & TÜBİTAK & BTK \\
\hline $\mathbf{2 0 1 1}$ & 314.607 & 677,957 & $1.413,611$ & $1.364,000$ \\
\hline $\mathbf{2 0 1 2}$ & 361.887 & $2.491,364$ & $1.561,970$ & $1.525,000$ \\
\hline $\mathbf{2 0 1 3}$ & 408.225 & $2.454,561$ & $2.176,376$ & $1.723,000$ \\
\hline $\mathbf{2 0 1 4}$ & 448.752 & $2.684,744$ & $2.439,738$ & $2.002,000$ \\
\hline $\mathbf{2 0 1 5}$ & 506.305 & $3.410,170$ & $3.179,413$ & $2.266,000$ \\
\hline $\mathbf{2 0 1 6}$ & 584.071 & $4.460,633$ & $3.250,685$ & $2.608,000$ \\
\hline $\mathbf{2 0 1 7}$ & 678.269 & $5.848,486$ & $3.475,906$ & $2.744,000$ \\
\hline $\mathbf{2 0 1 8}$ & 830.809 & $6.777,150$ & $4.804,257$ & $3.763,000$ \\
\hline $\mathbf{2 0 1 9}$ & 1.000 .027 & $9.214,084$ & $5.219,082$ & $4.697,000$ \\
\hline
\end{tabular}

Kaynak: SBB (2021b), Sanayi ve Teknoloji Bakanlığı (2020), TÜBİTAK (2020), BTK (2020)'den yararlanılarak oluşturulmuştur. 
oluşturulmasında, özel sektörün Ar-Ge çalışmalarının desteklenmesinde ve dijital dönüşümün hızlandırılmasında faydalı olduğu düşünülmektedir.

\section{SONUÇ}

İlk sanayi devriminden itibaren devrimi yakalayabilen ülkelerin küresel ekonomide rekabet güçlerini artırdığı görülmüştür. Bu kapsamda dijital dönüşümün sağlanmasında hükümetlere büyük sorumluklar düşmektedir. Nitekim gelişmiş ve gelişmekte olan birçok ülkede hükümetler dördüncü sanayi devrimine yönelik çalışmalar başlatmıştır. Bu ülkelerde, devrime yönelik kamu çalışmaları hazırlanan planlar, projeler, stratejiler veya yol haritaları ile yürütülmekte ve bu çalışmalar AR-GE harcamaları, destekler ve teşviklerle finanse etmektedir. Bu çerçevede dijital teknolojilere yapılan yatırımlar, dijital olmayan teknolojilere yapılan yatırımlara göre GSYH'ya yaklaşık yedi kat daha fazla katkı sağlamaktadır. Dolayısıyla teknolojik gelişmelerin büyümeyi çok daha fazla hızlandıracağ1nı söylemek mümkündür.

Osmanlı Devleti'nden bu yana 200 yıllık bir sanayileşme geçmişine sahip Türkiye Endüstri 2.0 ve 3.0 arasında bir yerde yer almaktadır. Dolayısıyla Türkiye'de de günümüzde kamu, hem aktif olarak dijital dönüşüm sürecinde rol alarak hem de destekler ve teşvikler yoluyla özel sektörün bu süreçte yer almasını sağlayarak dördüncü sanayi devrimi girişimlerini yürütmektedir.

Çalışma kapsamında incelenen Almanya, Çin, ABD ve Türkiye'de kamu kurumlarının genel olarak kamu-özel ortaklıkları AR-GE harcamaları, oluşturulan fonlar, programlar ve projelerle dördüncü sanayi devriminin gerektirdiği dijital dönüşüm sürecini desteklediği görülmektedir. Bu süreçte tüm ülkeler GSYH içindeki AR-GE harcamaları oranlarını artırmayı hedeflemiş ve belirlenen hedeflere ulaşılmasa da bu oranları artırmışlardır. Kamu kurumları tarafından sağlanan fonlar ve destekler de bu ülkelerin dijitalleşme sürecini hızlandırmıştır.

Dördüncü sanayi devrimi kapsamında oluşturulan tüm girişimler, stratejiler, planlar ve projelerde dijital teknolojilerin ülke içinde üretilmesi hedeflemektedir. Ancak bu plan, proje ve girişimler uzun dönemli olarak hazırlanması nedeniyle bu teknolojiler kısa dönemde bilgi iletişim teknolojileri mal ithalatının artırılmasını gerekli kılmaktadır. Nitekim incelenen ülkelerde dijital dönüşümün sağlanması için gerekli altyapının, bilgisayar, elektronik ve dijital teknoloji ekipmanların oluşturulmasında bilgi iletişim teknolojileri mal ithalatlarının genel olarak arttığı görülmektedir. Ancak örnek ülkelere kıyasla çok düşük oranlarda olan Türkiye BİT mal ithalatı oranı 2016 yılına kadar artış eğilimi gösterirken, döviz kurlarındaki artışın etkisiyle önemli bir düşüş yaşamıştır.
Dijital dönüşümün sağlanmasına yönelik gelişmeler, ülkelerin dijitalleşme başarısını gösteren yüksek teknoloji ihracatı üzerinde etkili olmuştur. Örneğin Almanya'da gerçekleştirilen çalışmalar toplam ihracat içerisindeki yüksek teknoloji ihracatı oranının artmasını sağlamıştır. Ancak son dönemlerde ABD ve Çin arasındaki ticaret savaşları bu iki ülkede yüksek teknoloji ihracatı ve BİT mal ithalatı oranlarının düşmesine neden olmuştur. Türkiye'de ise dalgalanmalar yaşayan yüksek teknoloji ihracatı oranı 2019 yılında artış gösterse de incelenen ülkelere kıyasla çok düşük oranlarda kalmaktadır. Türkiye'nin küresel rekabette güç kazanması için yüksek teknoloji üretimini ve ihracatını artırması son derece önemlidir.

İncelenen ülkelere bakıldığında seçili ülkelerin dijitalleşme sürecinde Türkiye'den çok daha başarılı olmasının sebebinin, bu ülkelerde özellikle teknoloji altyapısının ve nitelikli insan işgücünün mevcut olması ile belirlenen hedef ve uygulamaları Türkiye'ye göre daha sıkı bir biçimde takip etmesi ve bunları önemli miktarlarla desteklemesi olduğu söylenebilir. Bu nedenle Türkiye'nin de geçmişteki başarısızlıklardan ders alarak planlanan hedefleri sikı sıkıya takip etmesi, teknoloji altyapısını oluşturması ve nitelikli insan işgücünün yetiştirilmesi için eğitim sisteminin dijitalleşme süreci ile uyumlaştırması ve bunları popülizmden uzak politikalarla yürütmesi gerekmektedir.

Genel olarak dördüncü sanayi devriminin gerektirdiği yüksek teknoloji altyapısının kurulması için büyük finansman kaynaklarına ihtiyaç duymaktadır. Bu kapsamda kamu harcamalarının ekonomik sınıflandırması açısından teknoloji altyapısının oluşturulmasında yatırım harcamaları ilk aşamada artmaktadır. Teknoloji altyapısının oluşturulmasının ve hedeflere ulaşılmasının ardından ise yatırım harcamalarının azalması mümkün olacaktır. Dijitalleşme sürecinde özel sektör kuruluşlarının kendini geliştirmesi ve küresel pazarda yer alabilmesi için kamu tarafından hazırlanan fonlar, destekler veya teşviklerin toplam kamu harcamaları içindeki iktisadi transfer harcamalarını da artırması kaçınılmazdır. Bununla birlikte yatırım harcamalarında olduğu gibi özel sektörün bu fırsatları iyi değerlendirerek dijital dönüşümlerini tamamlaması, iktisadi transfer harcamalarının da zamanla azalmasını sağlayacaktır. Ayrıca kamu kurum ve kuruluşlarında ve kamu hizmetlerinin görülmesinde teknoloji altyapısının oluşturulması da başlangıçta kamu harcamalarının artmasına neden olacaktır. Ancak bu teknoloji altyapısının oluşturulması ve dijital dönüşümün tamamlanmasinın ardından kamu kurumlarında bu teknolojilerin kullanılmaya başlanması kaynak israfının, personel ve belge yükünün azalmasını sağlayarak cari harcamaların azalmasında etkili olacaktır.

Dördüncü sanayi devrimi ile hız kazanan otomasyon, robotik teknolojiler vb. gibi dijital teknolojilerin insan istihdamını azaltacağı düşünülmektedir. Ortaya çıka- 
cak işsizlik sorunlarının artması vatandaşların gelir elde edememelerine ve dolayısıyla vergi ödeyememelerine, sosyal güvenlik kayıplarının yaşanmasına ve dolaylı olarak kamu gelirlerinin de azalmasına ve hatta dolaylı olarak piyasanın durgunlaşmasına ve ekonomi üzerinde olumsuz etkilere neden olacaktır. $\mathrm{Bu}$ nedenle toplumun refahının artırılması ve ekonomik istikrarın sağlanması için işsiz kalan bireylere koşulsuz temel gelir benzeri yardımların yapılması gerekecektir. Bu yardımlar sosyal transfer harcamalarının artmasina neden olabilecektir.

Sonuç olarak dördüncü sanayi devrimine uyum sağlamak amacıyla kamu girişimi, kamu özel ortak girişimler veya özel girişim fark etmeksizin tüm girişimlerde hükümetler finansal destek sağlamaktadır. Bu durum kamu harcamalarının artmasına neden olmuştur. Artan kamu harcamaları ile oluşturulan teknoloji altyapısı ve geliştirilen teknolojiler dördüncü sanayi devriminin daha da gelişmesine katkı sağlamaktadır. Bu kapsamda yapılan harcamaların dördüncü sanayi devrimini geliştirmesi nedeniyle dördüncü sanayi devrimi ve kamu harcamaları arasında karşılıklı bir etkileşim olduğunu söylemek de mümkündür. Nihayetinde dördüncü sanayi devriminin gelişimi ve dijitalleşmenin tamamlanmasının ardından elde edilecek avantajlar göz önüne alındığında artan kamu harcamaları rolü son derece önemlidir.

\section{KAYNAKÇA}

AROND, E. \& BELL, M. (2009). Trends in the Global Distribution of R\&D since the 1970s: Data, Their Interpretation and Limitations, STESPS Working Paper 39, Brighton: STEPS Centre.

BLOOMBERG NEWS (2019). China to Funnel \$29 Billion Towatds its Chip Ambitions. 29 Oct. 2019 [online], https://www. bloomberg.com/news/articles/2019-10-29/china-to-funnel-29billion-towards-its-chip-ambitions, [Erişim Tarihi: 14 Temmuz 2020].

BMBF (2019). The High-Tech Strategy 2025 Progress Report. Rostock, Germany: BMBF, [online],https://www.bmbf.de/upload filestore/pub/The_High_Tech_Strategy_2025.pdf, [Erişim Tarihi: 08 Haziran 2020].

BMBF (2020). Research and Innovation. [online], https://www. datenportal.bmbf.de/portal/en/research.html, [Erişim Tarihi: 13 Mart 2020].

BOROUSH, M. (2021). U.S. R\&D Increased by $\$ 51$ Billion, to $\$ 606$ Billion, in 2018; Estimate for 2019 Indicates a Further Rise to $\$ 656$ Billion. InfoBrief NCSES, NSF 21-324, 1-7.

BTK (2020). Faaliyet Raporlart. [online], https://www.btk.gov.tr/ faaliyet-raporlari, [Erișim Tarihi: 23 Haziran 2020].

BTSB (2018a). Türkiye'nin Sanayi Devrimi: Dijital Türkiye Yol Haritast. [online], https://www.gmka.gov.tr/dokumanlar/
yayinlar/2023_Dijital-Turkiye-Yol-Haritasi.pdf, [Erişim Tarihi: 10 May1s 2020].

BTSB (2018b). Sanayide Yüksek Teknolojiye Geçiş Programı. Türkiye Sanayi Zirveleri, Şubat-Mayıs 2018. [online], http://www. karabuktso.org.tr/dosyalar/Sanayide $\% 20 \mathrm{Y} \% \mathrm{C} 3 \% \mathrm{BCksek} \% 20$ Teknolojiye $\% 20 \mathrm{Ge} \% \mathrm{C} 3 \% \mathrm{~A} 7 \mathrm{i} \% \mathrm{C} 5 \% 9 \mathrm{~F} \% 20$ Program $\% \mathrm{C} 4 \% \mathrm{~B} 1$. pdf, [Erişim Tarihi: 10 Mayıs 2020].

BTYK (2016). 2016/101 no.lu Akull Üretim Sistemlerine Yönelik Çalışmaların Yapılması Kararı. [online], https://www.tubitak.gov. tr/sites/default/files/2016 101.pdf, [Erişim Tarihi: 7 Mayıs 2020].

CHEN, S. (2020). Two Sessions 2020: China Cuts Science Butget by 9 Per Cent but National R\&D stil Tipped to Grow. South China Morning Post, May 22, 2020 [online], https://www.scmp.com/ news/china/science/article/3085672/two-sessions-2020-chinacuts-science-budget-9-cent-national-rd, Erişim Tarihi: 15 Haziran 2020].

CGTN (2021). China's R\&D Spending Rises to Record 2.4\% of GDP in 2020. 1 Mar 2021, [online], https://news.cgtn.com/ news/2021-03-01/China-s-R-D-spending-rises-to-record-2-4-ofGDP-in-2020-YhqaulWMx2/index.html [Erişim Tarihi: 15 Mayıs 2021].

ÇETINNKAYA, G. \& AKAR, S. (2020). Kamu Sektöründe Yetenek 4.0. içinde Çalışma Yaşamında Yetenek 4.0. Ed. S. Nart. ss. 193219, İstanbul: Beta Yayınevi, Birinci Baskı, ISBN: 978-605-242837-5.

DESTATIS STATISTISCHES BUNDESAMT (2021). Education, Reserarch and Culture, Research and Development. [online], https://www.destatis.de/EN/Themes/Society-Environment/ Education-Research-Culture/Research-Development/_node.html, [Erişim Tarihi: 15 Mayıs 2021].

DURSUN, S. \& ŞENGÜL, B. (2018). Sanayi 4.0 ve Türkiye: Genel Bir Değerlendirme. Türk Metal. 222, 68-73.

EBSO (2015). Sanayi 4.0: Uyum Sağlayamayan Kaybedecek. İzmir: Ege Bölgesi Sanayi Odası Araştırma Müdürlüğü.

EĞİLMEZ, M. (2019). Tarihsel Süreç Iç̧inde Türkiye Ekonomisi. İstanbul: Remzi Kitabevi, Yedinci Bask1, ISBN: 978-975-14-18760 .

EXPORT.GOV (2019). China - Technology and ICT. 7.30.2019, [online], https://www.export.gov/apex/article2?id=ChinaTechnology-and-ICT, [Erişim Tarihi: 2 Haziran 2021].

FREEMAN, C. \& SOETE, L. (2003). Yenilik İktisadl. Çeviren: E. Türkcan. Ankara: TÜBİTAK Akademik Dizi, Üçüncü Baskı, ISBN: 9789754032918

GÖRÇÜN, Ö. F. (2017). Dördüncü Endüstri Devrimi: Endüstri 4.0. İstanbul: Beta Yayınc1lık, İkinci Baskı, ISBN: 978-605-333-662-4.

GÜR, N., ÜNAY, S. \& DİLEK, Ş. (2017). Sanayiyi Yeniden Düşünmek: Küresel Teknolojik Dönüşümün Dünya ve Türkiye Ekonomisine Yansımaları. İstanbul: SETA, Birinci Baskı, ISBN: 9789752459229

HARRIS, R. (2004). Government and the Economy, 1688-1850. içinde The Cambridge Economic History of Modern Britain. Eds: R. Floud \& P. Johnson. ss. 204-237, Cambridge: Cambridge 
University Press, Birinci Baskı, ISBN: 978-0521527361.

HOBSBAWM, E. J. (1998). Sanayi ve Imparatorluk. Çeviren A. Ersoy. Ankara: Dost Kitabevi.

HUAWEI \& OXFORD ECONOMICS (2017). Digital Spillover: Measuring the true impact of the Digital Economy. [online] https://www.huawei.com/minisite/gci/en/digital-spillover/files/ gci digital spillover.pdf, [Erișim Tarihi: 6 Haziran 2021]

HUIFENG, H. (2019). China Looks to Raise an Extra US\$7.1 Billion to Support Hi-tech Manufacturing. South China Morning Post, 3 Nov. 2019 [online], https:/www.scmp.com/economy/ china-economy/article/3036108/china-looks-raise-extra-us71billion-support-hi-tech, [Erişim Tarihi: 14 Temmuz 2020].

İLGÜN, M.F. (2020). Endüstri 4.0 ve Kamu Maliyesinde Dönüşüm: Kamu Harcamaları Açısından Bir Değerlendirme. Sosyoekonomi. 28(44), 237-260

KAGERMANN, H., HELBIG, J., HELLINGER, A., \& WAHLSTER, W. (2013). Recommendations for Implementing the Strategic Initiative INDUSTRIE 4.0: Securing the Future of German Manufacturing Industry. Final Report of the Industrie 4.0 Working Group. Forschungsunion.

KAGERMANN, H., ANDERL, R., GAUSEMEIER, J., SCHUH, G. \& WAHLSTER, W. (2016). Industrie 4.0 in a Global Context: Strategies for Cooperating with International Partners. (Acatech Study), Munich: Herbert Utz Verlag 2016, ISSN: 2192-6174.

KAL'A, A. (2003). Osmanlı Esnafı ve Sanayisi Üzerine Yapılan Çalışmalarla İlgili Genel Bir Değerlendirme. Türkiye Araştırmaları Literatür Dergisi. 1 (1), 245-266.

KLITOU, D., CONRADS, J., RASMUSSEN, M., CARSA, PROBST, L. \& PEDERSEN, B., PwC (2017). Digital Transformation Monitor Germany: Industrie 4.0. European Commission, European Union.

KÜÇÜKKALAY, A. M. (1997). Endüstri Devrimi ve Ekonomik Sonuçları Analizi. Süleyman Demirel Üniversitesi İktisadi ve İdari Bilimler Fakültesi Dergisi. 2, 51-68.

LI, L. (2018). China's Manufacturing Locus in 2025: Wiht a Comparison of 'Made-in-China 2025' and 'Industry 4.0'. Technological Forecasting \& Social Change. 135, 66-74.

LIU, S. X. (2016). Innovation Design: Made in China 2025. Design Management Review. 27(1), 52-58.

MACDOUGALL, W. (2018). Industrie 4.0: Germany Market Report and Outlook. Berlin: GTAI, Germany Trade and Invest Gesellschaft für Außenwirtscaft und Standortmarketing mbH.

MANUFACTURING USA (2019). Annual Report 2018. [online] https://nvlpubs.nist.gov/nistpubs/ams/NIST.AMS.600-5.pdf, [25 May1s 2020]

MARKA ve BİLIŞìM VADİSİ (2019). Bilişim Çalıştayı Doğu Marmara Bilişim Sektörü ve Bilișim Vadisi Strateji Geliştirme Çalıștayı Sonuç Raporu. [online], http://www.marka.org.tr/ uploads/files/2019-bilisim-calistayi.pdf, , [Erişim Tarihi: 7 Ağustos 2020].

MARKA ve MUALLIMKÖY TEKNOPARK A.Ş. (2013). Bilişim Vadisi ÇalıştayRaporu. [online], https://www.kalkinmakutuphanesi. gov.tr/assets/upload/dosyalar/bili-c5-9fim-vadisi-c3-87al-c4-b1c5-9ftay-c4-b1-sonu-c3-a7-raporu-marka-2014.pdf, [Erișim Tarihi: 7 Ağustos 2020]

MILWARD, R. \& SHEARD, S. (1995). The Urban Fiscal Problem, 1870-1914: Government Enpenditure and Finance in England and Wales. The Economic History Review. New Series, 48(3), 501-535.

OECD (2009). OECD Science, Technology and Industry Scoreboard 2009. Paris, France: OECD Publishing, ISBN: 978-92-64-07543-6.

ÖZHAN, T. (2016). Makinelerin Evrimi: 4. Sanayi Devrimi. İstanbul: e-Kitap Projesi, ISBN: 978-605-9285-93-3.

PLATFORM INDUSTRIE 4.0 (2019). Platform Industrie 4.0Digital Transformation “Made in Germany”. Ostbevern, Germany: MKL Druck GmbH \& Co. KG

RESMİ GAZETE (2018). Cumhurbaşkanlığı Teşkilatı Hakkında Cumhurbaşkanlığı Kararnamesi (Kararname Numarası: 1), 10 Temmuz 2018 Tarihli ve 30474 Sayılı Resmi Gazete.

RIFKIN, J. (2014). Üçüncü Sanayi Devrimi, Yanal Güç, Enerjiyi, Ekonomiyi ve Dünyayı Nasıl Dönüştürüyor?. Çevirenler: P.Sıral \& M. Başekim. İstanbul: İletişim Yayınları, Birinci Baskı, ISBN: 9789750516795.

ROJKO, A. (2017). Industry 4.0 Concept: Background and Overview. International Journal of Interactive Mobile Technologies (iJIM). 11(5), 77-90

SANAYİ VE TEKNOLOJİ BAKANLIĞI (2020). Faaliyet Raporlart. [online], https://www.sanayi.gov.tr/plan-programraporlar-ve-yayinlar/faaliyet-raporlari, [Erişim Tarihi: 23 Haziran 2020].

SCHWAB, K. (2017). Dördüncü Sanayi Devrimi. Çeviren: Z. Dicleli. İstanbul: Optimist Yayın, Birinci Baskı, ISBN: 978-605322-295-8.

SBB (2021a). 2021 Yllı Bütçe Gerekçesi. [online], https://www.sbb. gov.tr/wp-content/uploads/2021/02/2021 Yili_Butce_Gerekcesi. pdf, [Erişim Tarihi: 17 Mayıs 2021]

SBB (2021b). Merkezi Yönetim Bütçe Gerçekleşmeleri ve Beklentiler Raporlart. [online], https://www.sbb.gov.tr/butcemerkezi-yonetim-butce-gerceklesmeleri-ve-beklentiler-raporlari/, [Erişim Tarihi: 3 Haziran 2021].

TÜİK (2020). Merkezi Yönetim Bütçesinden AR-GE Faaliyetleri Íçin Ayrılan Ödenek ve Harcamalar, 2020. Sayı: 22678, Haber Bülteni. [online] https://data.tuik.gov.tr/Bulten/Index?p=MerkeziYonetim-Butcesinden-AR-GE-Faaliyetleri-Icin-Ayrilan-Odenekve-Harcamalar-2020-33678, [Erişim Tarihi: 16 Mayıs 2021].

TÜBİTAK (2016). Yeni Sanayi Devrimi Aklll Üretim Sistemleri Teknoloji Yol Haritasl. [online],https://www.tubitak.gov.tr/sites/ default/files/akilli_uretim_sistemleri tyh_v27aralik2016.pdf, [Erişim Tarihi: 9 Ekim 2018].

TÜBİTAK (2020). 2011-2019 Faaliyet Raporlar1 [online], https:// www.tubitak.gov.tr/tr/icerik-faaliyet-raporlari, [Erișim Tarihi: 23 Haziran 2020]

TÜSİAD ve BCG GROUP (2016). Türkiye'nin Küresel Rekabetçiliği İçin Bir Gereklilik Olarak Sanayi 4.0: Gelişmekte olan Ekonomi Perspektifi. Eds: N. Numanoğlu, M.E. Eynehan, G. 
Morkoç-Nikelay \& E. Aksoy. Yayın No: TÜSİAD-T/2016-03/576, ISBN: 978-605-165-016-6.

UNIDO (2015). Industrial Development Report 2016, The Role of Technology and Innovation in Inclusive and Sustainable Industrial Development. Vienna, ISBN: 978-92-1-106454-4.

WORLD BANK DATA (2021). Indicators of Research and Development Expenditure (\% of GDP), ICT Goods Imports (\% total goods imports), and High-Technology Exports (\% of manufactured exports). [online], https://data.worldbank.org/, [Erişim Tarihi: 13 Mayıs 2021]

WORLD ECONOMIC FORUM \& A.T KEARNEY (2018). Readiness for the Future of Production Report 2018. Insight Report. Cologny/ Geneva, Switzerland, ISBN: 978-944835-16-3.

WÜBBEKE, J., MEISSNER, M., ZENGLEIN, M.J., IVES, J. \& CONRAD, B. (2016). Made in China 2025: The Making of a High-tech Superpower and Consequences for Industrial Countries. Mercator Institute for China Studies, Papers on China, No 2, ISBN: 2509-5862.

YANKIN, F.B. (2019). Dijital Dönüşüm Sürecinde Çalışma Yaşamı. Trakya Üniversitesi İktisadi ve İdari Bilimler Fakültesi Dergisi. 7(2), 1-38. 